\title{
Early hominin landscape use in the Lower Omo Valley, Ethiopia: Insights from the taphonomical analysis of Oldowan occurrences in the Shungura Formation (Member F)
}

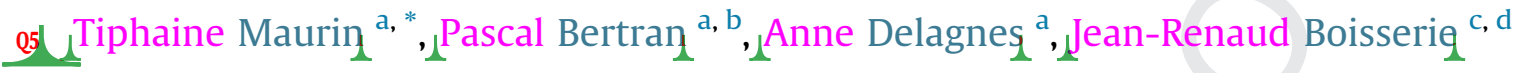 \\ ${ }^{a}$ University of Bordeaux/CNRS, PACEA, bâtiment B8, allée Geoffroy-Saint-Hilaire, CS 50023, 33615, Pessac cedex, France \\ ${ }^{\mathrm{b}}$ Institut national de recherches archéologiques préventives, 140 avenue du Maréchal Leclerc, 33130, Bègles, France \\ ' CNRS/French Ministry of Europe and Foreign Affairs, French Center for Ethiopian Studies, P.O. Box, 5554, Addis Abeba, Ethiopia \\ d CNRS/University of Poitiers, IPHEP, 6, rue Michel-Brunet, 86000, Poitiers, France
}

\section{A R T I C L E I N F O}

\section{Article history:}

Received 11 October 2016

Accepted 23 June 2017

Available online $\mathrm{xxx}$

\section{Keywords:}

Oldowan

Shungura Formation

Omo

Taphonomy

Lithic

Spatial behavior

\begin{abstract}
A B S T R A C T
The Oldowan archeological record of the Shungura Formation, Member F (Lower Omo valley, Ethiopia) comprises more than one hundred occurrences distributed within archeological complexes where multiple small spots were found in association with one or two larger occurrences. Such spatial patterning could reflect hominin spatial behavior, repeated occupations within a single sedimentary unit, or taphonomic and/or collection biases. Here we test these hypotheses by way of a geoarcheological and taphonomical analysis using four criteria to assess the preservation of the lithic assemblages: (1) size composition, (2) artifact abrasion, (3) bone abrasion, and (4) orientations of lithic artifacts and bones (i.e., fabrics). We propose a new model of taphonomically induced spatial patterning where the multiple, small well circumscribed occurrences result primarily from post-depositional processes and therefore do not reflect any underlying behavioral patterns. The large number of archeological occurrences documented in Member F, therefore, corresponds to a limited number of primary occupations $(<10)$. The archeological occupation is mainly restricted to the lower part of Member $F$ and may reflect a single or a small number of occupation episodes, which were located on previous levees of the paleo-Omo River, in nearby floodplain areas, or on the riverbank. This strongly suggests that most of the knapping activities originally took place close to the river. This preference of the Omo toolmakers for riverine environments could explain the scarcity of archeological material in the upper part of Member F that comprises primarily distal floodplain sedimentary facies.
\end{abstract}

(c) 2017 Elsevier Ltd. All rights reserved.

\section{Introduction}

A significant number of recent studies have greatly improved our understanding of technological skills shared by Oldowan toolmakers in eastern Africa (Isaac and Harris, 1997; Ludwig, 1999; de la Torre et al., 2003, 2004; Delagnes and Roche, 2005; Mora and de la Torre, 2005; Hovers, 2009; Braun et al., 2009a; Faisal et al., 2010; Stout et al., 2010; Barsky et al., 2011; Yustos et al., 2015), including aspects of raw material provisioning (Stout et al., 2005; Blumenschine et al., 2008; Braun et al., 2008, 2009a, b; Harmand, 2009; Goldman-Neuman and Hovers, 2012). By contrast, very little is known about patterns of landscape use (Blumenschine, 2003)

\footnotetext{
* Corresponding author.

E-mail address: tiphaine.maurin@gmail.com (T. Maurin).
}

despite their being crucial for assessing the abilities of hominins to adapt to varying environmental conditions. Site distribution, density, and spatial extension in the Oldowan differ significantly from one context to another. Contexts with a limited number of dense and well circumscribed archeological occurrences, such as Hadar (Kimbel et al., 1996), Lokalalei (Roche et al., 2003), Kanjera South (Plummer et al., 1999), Melka Kunture (Chavaillon and Piperno, 2004), Fejej (de Lumley and Beyene, 2004), and Nyabusosi (Pickford et al., 1989) contrast with contexts comprising multiple small spots associated with one or two more consequential occurrences. This latter type of spatial patterning is characteristic of the Oldowan archeological record of Gona (Semaw, 2000), Peninj (de la Torre et al., 2003), Koobi Fora (Harris, 1997), Olduvai Gorge (Leakey and Clark, 1971; Blumenschine et al., 2012), and Shungura Formation-Member F (Lower Omo valley, Ethiopia), where our 
recent surveys revealed the presence of more than one hundred occurrences at a micro-regional scale, mostly clustered within a limited number of archeological complexes (Delagnes et al., 2011; Delagnes, 2012).

Such spatial patterning suggests three non-mutually exclusive hypotheses: (1) these occurrences relate directly to hominin spatial behavior, either as an adaptive response to the specific characteristics of the meandering landscape of the paleo-Omo River (Delagnes et al., 2011) or as a result of a functional complementarity between "mini-" and "macro-sites" reflecting a home-based spatial behavior, as suggested by Isaac at Koobi Fora (Isaac, 1981; Isaac et al., 1981); (2) they correspond to repeated but still indistinguishable occupational phases within a single sedimentary unit; and/or (3) they reflect taphonomic and/or site inventory biases.

Here we test these hypotheses by way of a geoarcheological and taphonomical analysis of the archeological occurrences from the Shungura Formation-Member $F$, dated to between $2.32 \pm 0.02$ million years $(\mathrm{Ma})$ and $2.27 \pm 0.04 \mathrm{Ma}(\mathrm{McD}$ ougall and Brown, 2008; McDougall et al., 2012). Although fine-grained alluvial sedimentation is favorable to the good preservation of archeological sites, several studies have demonstrated such contexts do not systematically guarantee the integrity of the lithic assemblages (Isaac, 1967; Schick, 1987; Sitzia et al., 2012). Taphonomic analyses of Oldowan sites are currently limited to single criteria, for instance fabrics at Kanjera South (Plummer et al., 1999) or artifact breakage by trampling or sediment compaction in A.L. 894 at Hadar (Hovers, 2003). Our multi-dimensional analysis combines an investigation of the spatial and stratigraphic distribution of archeological occurrences within the meandering Omo River context that prevailed during the deposition of Member F, with a taphonomic approach that considers artifact size sorting, edge abrasion, bone surface modifications, and fabric analysis. Based on these data, we propose a taphonomically induced spatial model, which provides key insights for understanding the spatial behavior of toolmakers in the Shungura Formation relative to the other Oldowan site complexes.

\section{Materiel and methods}

The Shungura Formation is located along the Omo Valley in the East African Rift system of southwestern Ethiopia (Fig. 1). The archeological potential of this area has been documented and investigated since the late 1960s and early 1970s by the International Omo Research Expedition (IORE), which focused primarily on Member F. Jean Chavaillon (1976) and Harry Merrick (1976) excavated seven archeological occurrences. Artifacts were piece-plotted and numbered, with the associated sediment sieved and sorted (Rensberger, 1973). The homogeneous lithic assemblages are composed primarily of small quartz flakes, flake fragments, angular fragments, and cores (Chavaillon, 1976; Merrick and Merrick, 1976; Ludwig, 1999; de la Torre et al., 2004). Although extremely abundant in the overall Shungura sequence, faunal remains are scarce in the archeological occurrences.

The Omo Group Research Expedition (OGRE) restarted multidisciplinary fieldwork in the Shungura Formation in 2006, including paleontological, archeological, and geological analyses and paleoenvironmental reconstructions (Boisserie et al., 2008). Outcrops assigned to Members B to G of the Shungura Formation (type area, see de Heinzelin, 1983) were extensively surveyed in order to refine the temporal and spatial extent of hominin occupation in the area (Boisserie et al., 2010; Delagnes et al., 2011). Only Member $F$ and the lower part of Member $G$ yielded unquestionable archeological occurrences, which have been dated to between approximately $2.3 \mathrm{Ma}$ and $2.0 \mathrm{Ma}$ within a stratigraphic sequence that ranges from 3.6 Ma to 1.0 Ma.

\subsection{Archeological data}

Our study focuses on six complexes of archeological occurrences, OMO 79, OMO 1/E, OMO 123, FtJi 1-3-4, FtJi 2, and FtJi 5 (Fig. 1, Supplementary Online Material [SOM] Table S1), for which both excavation and surface collection data are available. Artifacts in Member $\mathrm{F}$ are not randomly distributed across the outcrops (Delagnes et al., 2011; Delagnes, 2012; Maurin et al., 2014) but cluster in areas designated here as "archeological complexes" (Figs. 1 and 2; Maurin et al., 2014). Such archaeological complexes correspond to specific areas within Member $\mathrm{F}(<1 \mathrm{ha})$, where at least one dense occurrence is found in spatial proximity and stratigraphic continuity with multiple smaller occurrences. The stratigraphic position of occurrences forming each archeological complex can be inferred with a high degree of confidence when artifacts were visibly eroded from the outcrops. Artifacts are either in situ (i.e., still embedded in the sediment), sub-in situ (i.e., the layer of origin is clearly identifiable), or redistributed on the slope by erosion.

Here we present an analysis of 4000 artifacts from both the IORE and OGRE field investigations: OMO 123 (Chavaillon, 1976 and unpublished data from Delagnes and colleagues), Ftji 1-3-4, Ftji 2, FtJi 5 (Merrick and Merrick, 1976), OMO 1/E, and OMO 123 (unpublished data from Delagnes and colleagues). Artifacts are generally small (Chavaillon, 1976; Merrick and Merrick, 1976) and primarily made of quartz $(97.3 \%, n=3892)$. Lithic objects less than $5 \mathrm{~mm}$ in width were excluded from the analysis in order to render them directly comparable with assemblages that derive from excavated and sieved material, and from non-sieved surface assemblages.

2.1.1. Ftji 1-3-4 Located in the northern part of the type area, the FtJi 1-3-4 complex was studied by H. Merrick in the early 1970s, who excavated one occurrence (OMO A16) with in situ artifacts in a lens of sand and fine gravels. He also collected material from two others (OMO A17 and OMO A18) by scraping and screening the soft upper $10 \mathrm{~cm}$ of the deposit (Merrick, 1976; Merrick and Merrick, 1976; IORE archives). All of these occurrences were located at the base of an approximately $10 \mathrm{~cm}$ thick sandy layer some $6 \mathrm{~m}$ above Tuff $\mathrm{F}^{\prime}$ that cuts and laterally replaces Tuff $\mathrm{F}$ (de Heinzelin, 1983; Howell et al., 1987).

2.1.2. FtJi 2 This single occurrence (OMO A2) was excavated by $\mathrm{H}$. Merrick (Merrick and Merrick, 1976). The majority of the artifacts were found (SOM Table S1) embedded in situ within a clay rich in white nodular $\mathrm{CaCO}_{3}$ concretions approximately $6 \mathrm{~m}$ above Tuff F' (Merrick and Merrick, 1976; de Heinzelin, 1983; and Merrick's IORE archives). This locally reworked deposit was previously referred to as Tuff $F^{\prime} \gamma$ (Merrick, 1976; de Heinzelin, 1983; Howell et al., 1987).

2.1.3. Ftji 5 This complex is composed of eight occurrences (OMO A19, OMO A95, OMO 97, OMO A98, OMO A99, OMO A101, OMO A102, and OMO A103) all located in Tuff $F^{\prime}$ or in a sandy layer overlaying Tuff $\mathrm{F}$. Our study focused one occurrence at the base of a hill just above a large indurated tuff slab excavated by $\mathrm{H}$. Merrick (OMO A19; Merrick and Merrick, 1976). While several artifacts (23 of 107) were found in a coarse sand and gravel layer, the majority are surface finds (SOM Table S1). OGRE recorded seven other occurrences in the vicinity (OMO A95, OMO 97, OMO A98, OMO A99, OMO A101, OMO A102, and OMO A103) from which no artifacts were collected.

2.1.4. OMO 123 This complex, discovered in 1972 (Coppens et al., 1973; Chavaillon, 1974), comprises 15 occurrences, the majority of which yielded in situ or sub-in situ artifacts. The assemblages were collected from a sandy layer and overlying loamy deposit (Fig. 3), forming a sub-continuous $0.5 \mathrm{~m}$ thick archeological layer (Fig. 4). Three occurrences (OMO A13, OMO A12, and OMO A15) 


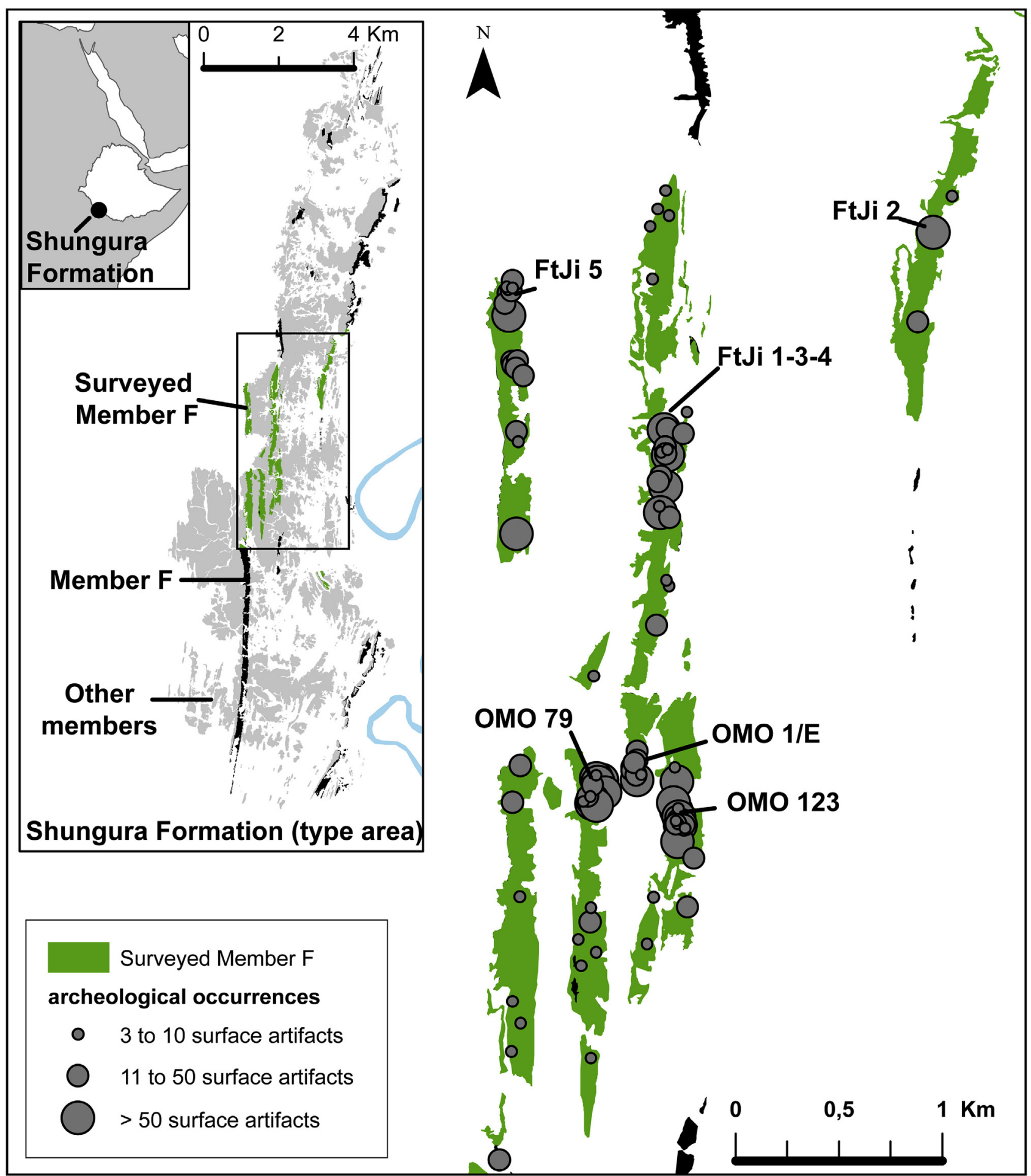

Figure 1. Archeological occurrences and studied complexes of the surveyed Member F (Shungura Formation, type-area).

were excavated by J. Chavaillon (1976, 1980). New surface finds and in situ artifacts recorded by OGRE were also analyzed. A. Delagnes, P. Haesaerts, and M. Brenet dug seven test pits in 2010 in order to provide further detail concerning the stratigraphic position of the artifacts from OMO A9, OMO A11, OMO A12, OMO A13, OMO A14, OMO A64, and OMO A65.

2.1.5. OMO 1/E The archeological complex OMO 1/E, discovered by the OGRE project in 2008 (Delagnes et al., 2011), comprises six well delimited occurrences (Fig. 2), three of which yielded in situ archeological assemblages (OMO A31, OMO A32, and OMO A33). Test pits were dug in OMO A32, OMO A33, and OMO A34 in 2008, and OMO A32 was excavated in 2010 under the direction of A. Delagnes. Only six artifacts were found in situ, while 385 artifacts associated with abundant faunal remains were collected during scraping and screening of the soft upper $10 \mathrm{~cm}$ of the deposit. The three northern occurrences are located in sands, approximately $5 \mathrm{~m}$ above Tuff $\mathrm{F}$, with the three southern ones found in the overlaying silt layer (Fig. 5). 


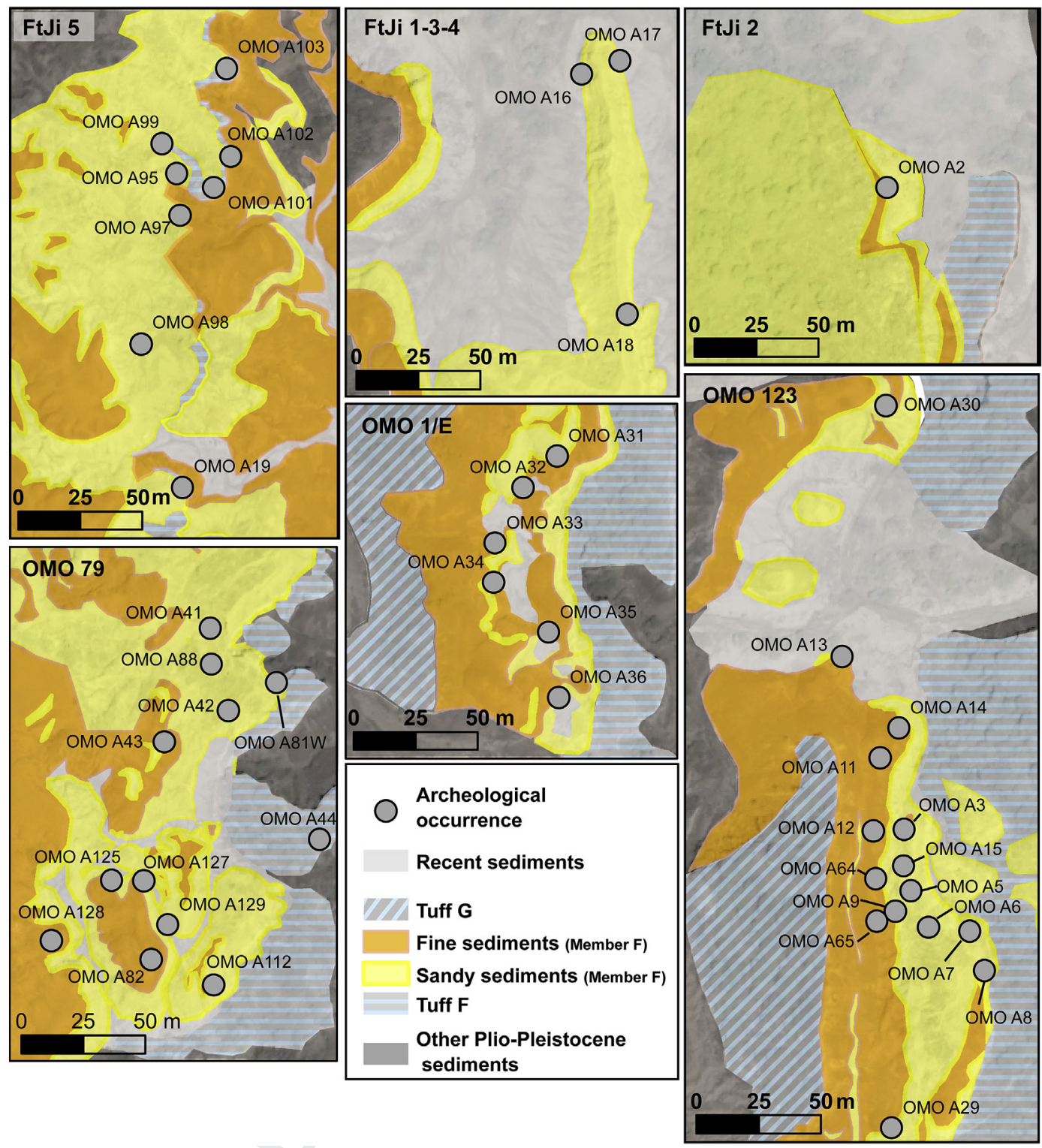

Figure 2. Maps of the six studied archeological complexes containing archeological occurrences and exposed sediments.

2.1.6. OMO 79 The archeological occurrences at OMO 79 were discovered in 2008 by the OGRE project (Delagnes et al., 2011). Our study focuses on nine occurrences from this complex (OMO A88, OMO A81W, OMO A42, OMO A43, OMO A125, OMO A127, OMO A129, OMO A82, OMO A112); one comprises in situ artifacts (OMO A127), seven yielded sub-in situ artifacts, and one, only surface artifacts (SOM Table S1). Three of these occurrences are well circumscribed in loamy sediments (OMO A43, OMO A125, and OMO A82), whereas the others were collected from the sands (OMO A127/A129/A112, OMO A42/A88/A81W) around $4 \mathrm{~m}$ above Tuff $\mathrm{F}$. At OMO A42, artifacts were collected during the scraping and screening of the soft upper $5 \mathrm{~cm}$ of the sediment. Except for a higher proportion of coarse-grained sediments, the sedimentary sequence is similar to that of OMO 123 and OMO 1/E.

\subsection{Geological context of Member F}

In the Lower Omo Valley, Plio-Pleistocene subsidence associated with rifting resulted in the accumulation of a several kilometer thick sedimentary sequence, of which nearly $770 \mathrm{~m}$ ("the Shungura Formation") outcrops along normal faults. First mapped by de Heinzelin (1983), this complex succession of fluvial, lacustrine, and volcanic deposits has been divided into members separated by continuous volcanic tuffs forming benchmark levels in the landscape (Fig. 6). The tuffs have been dated by $\mathrm{K} / \mathrm{Ar}$ and ${ }^{40} \mathrm{Ar} /{ }^{39} \mathrm{Ar}$ methods (Feibel et al., 1989; McDougall and Brown, 2008), with Member F deposited between $2.32 \pm 0.02 \mathrm{Ma}$ (average ages for Tuff $\mathrm{F}$ at the base of Member F) and $2.27 \pm 0.04 \mathrm{Ma}$ (averaged ages for Tuff $G$ ).

2.2.1. Main architectural elements of Member F deposits Various sedimentary bodies were identified within Member F (lithofacies codes and architectural elements are adapted from Miall (1996) and Colombera et al., (2013)).

(1) Several hundred meters wide and 3-4 m thick lenses of sand. This lithofacies typically includes (from bottom to top): cross-bedded sands and gravels measuring $0.5-2 \mathrm{~cm}$ in diameter on average $(\mathrm{Gt})$, sometimes reduced to a single 
OMO 123
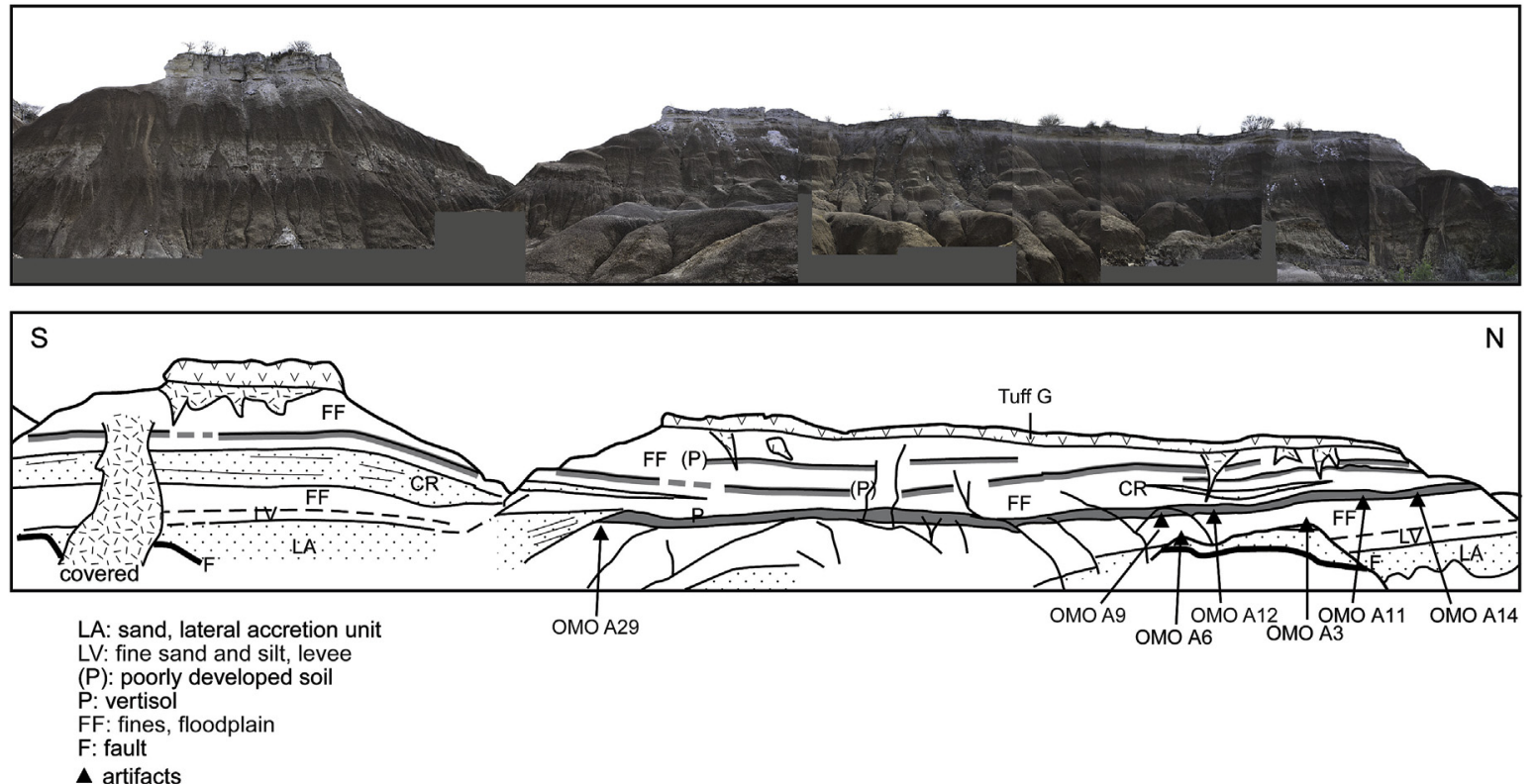

Figure 3. Composite view of OMO 123 and location of archeological occurrences.

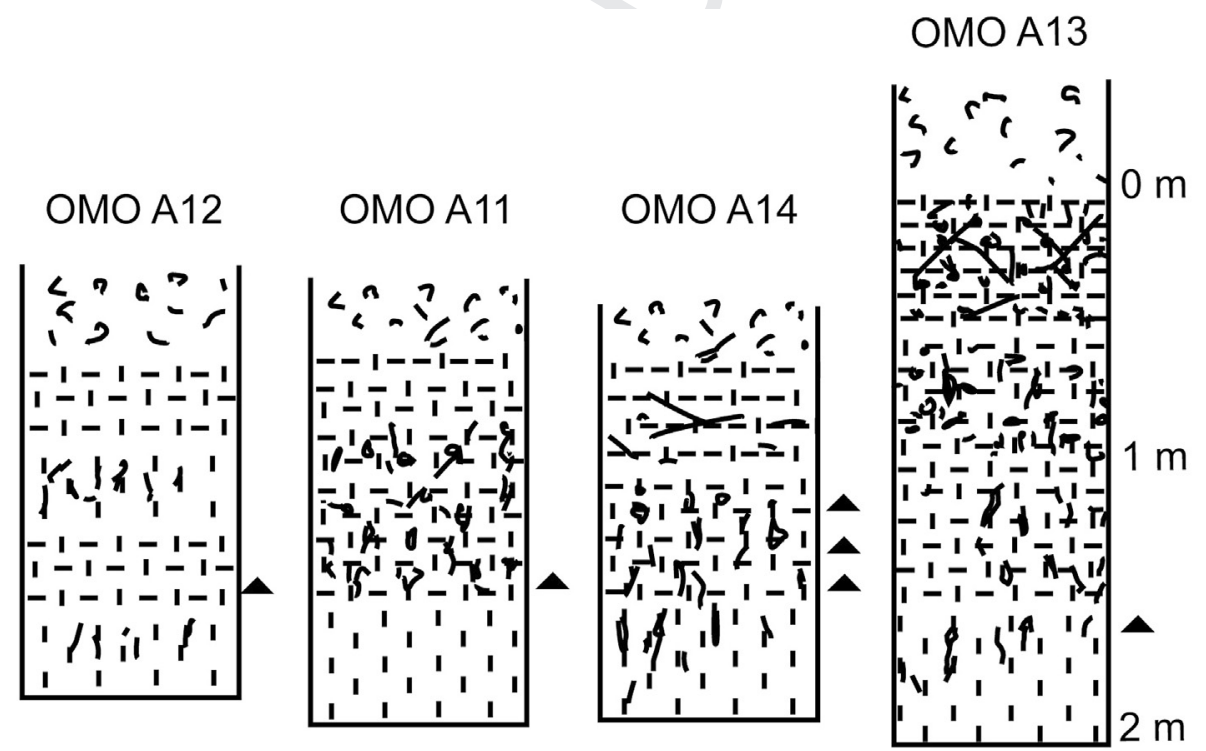

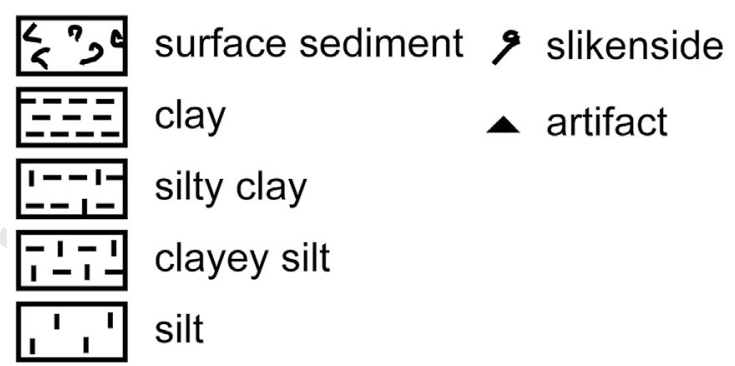

Figure 4. Schematic stratigraphy of the loamy archeological layer from the OMO 123 archeological complex. The artifact location(s) in each section is indicated by black triangles on the right.

channel lag; cross-bedded sands (St, thickness of individual sets $0.3-0.6 \mathrm{~m}$; SOM Fig. S1a); ripple-bedded sands ( $\mathrm{Sr}$, SOM Fig. S1b). At the scale of the outcrop, these units form low angle dipping strata that are slightly oblique to the basal erosional surface and reflect lateral accretion on point bars (LA element, Figs. 3 and 5). They are overlain by subhorizontal beds of fine sand and silt (Fl, SOM Fig. S1b), interpreted as levee deposits (LV element). These large-scale 

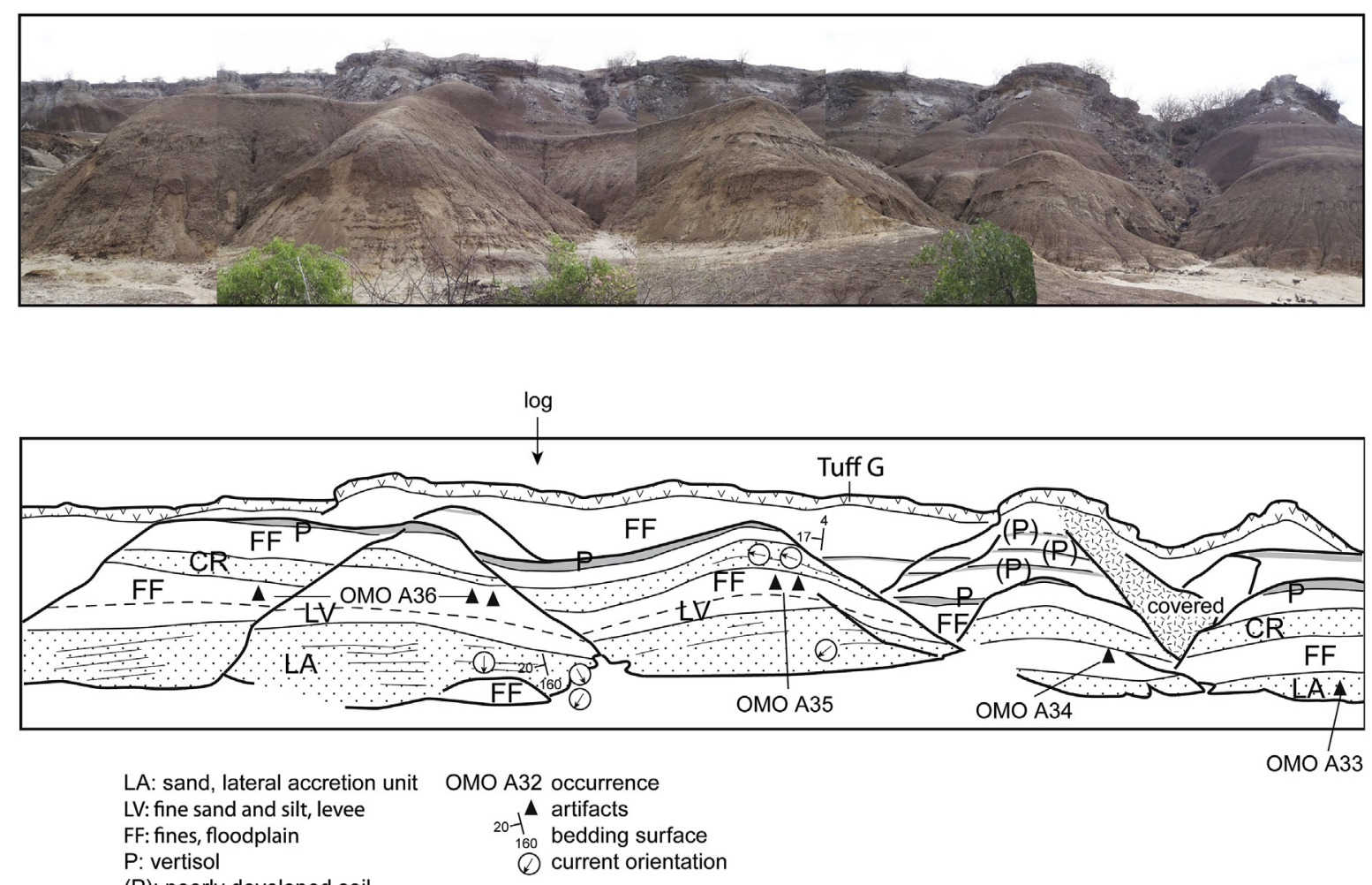

Tuff $G$

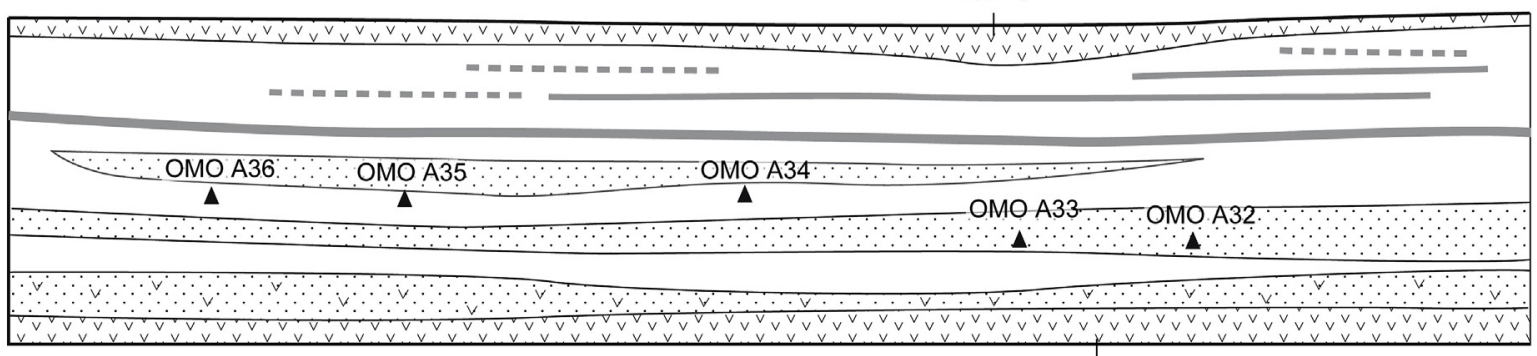

Tuff F

Figure 5. Composite view of OMO 1/E, location of the archeological occurrences, and schematic stratigraphy.

lenses were deposited in a meandering river system similar to the current Omo.

(2) Sand lenses measuring 10 to a few hundred meters wide and $0.5-2 \mathrm{~m}$ thick. These smaller lenses lack gravels and contain abundant mudballs and discontinuous silt drapes. They are interpreted as infilled crevasse channels (CR element, Figs. 3 and 5) or ephemeral tributaries of the main river.

(3) Fine-grained units (Fm) organized into a few meters thick strata sometimes showing a clear fining-upward trend in grain size and clay-rich paleosols. These floodplain deposits (FF elements) contain networks of desiccation cracks visible in several outcrops and gypsum crystals are frequent, suggesting a deficit in the water balance during deposition of the silts. The dark gray-brown to dark brown paleosols have vertic properties (i.e., well developed slickensides) and varying degrees of carbonate leaching (decalcified upper horizon, root and nodular concretions in the lower horizon). These paleosols reflect low accretion phases of the floodplain and subsequent differentiation of soil horizons under climatic conditions with marked seasonal contrasts (Eswaran et al., 1999).

(4) A few dozen centimeters to several meters thick volcanic tuffs usually capping the outcrops.

(5) Massive sub-continuous pumice-rich sand strata (Gm, Sm) overlaying the tuff units.

2.2.2. Lateral and vertical distribution of the sedimentary bodies Sediments exposed over several hundred meters with virtually no vegetation reveal a complex sedimentary sequence.

(1) The Ftji1-3-4 complex (Merrick, 1976) is dominated by sand bodies composed of large-scale interlocking lenses (multistorey elements) over almost the entire depth of the sequence. This sector corresponds to the migration band of the main channel.

(2) Complexes OMO 1/E, OMO 123, and OMO 79 are dominated by fine grained floodplain deposits with a few intercalated 


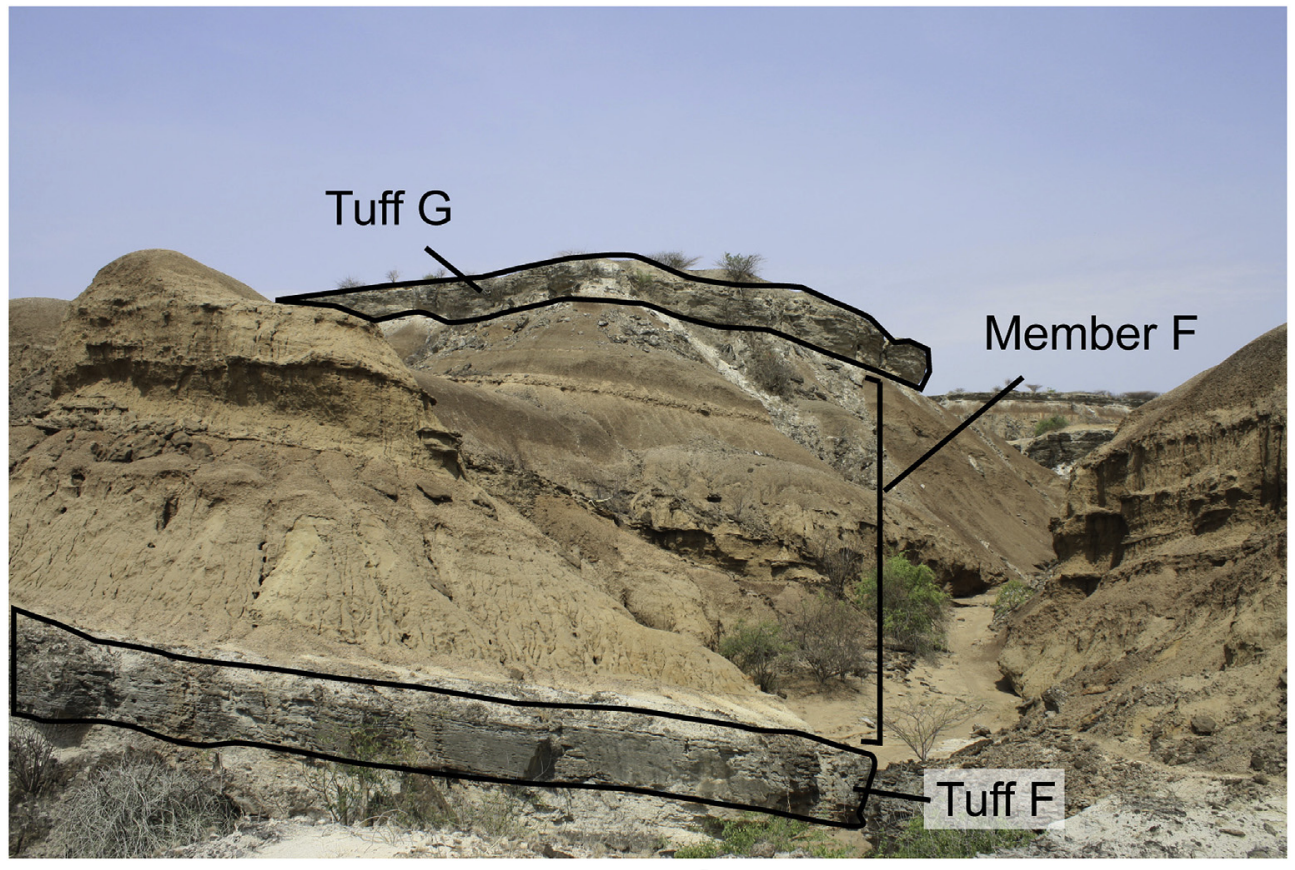

Figure 6. Member F sequence at OMO 79.

crevasse channel sand lenses. These complexes correspond to a marginal floodplain zone.

(3) The sand bodies are randomly distributed within the overall sequence, which may reflect the stochastic migration of the river in the subsiding basin (see model in Fig. 17) rather than true sedimentary cycles as proposed by de Heinzelin (1983).

(4) A fining-upward trend in grain size can be observed in some outcrops, particularly in the OMO 1/E and OMO 123 complexes. Sand bodies are abundant in the lower part of the sequence, with both their frequency and extension decreasing towards the top of the approximately $25 \mathrm{~m}$ high outcrop. As this pattern is not generally found in the study area, it is unlikely controlled by broader factors such as tectonics and climate. The model of an increasing distance to the active channel linked to the intrinsic evolution of the fluvial system is favored here.

\subsection{Methodology}

Four criteria were used to assess the preservation of the lithic assemblages: (1) size composition, (2) artifact abrasion, (3) bone abrasion, and (4) orientation of lithic artifacts and bones (i.e., fabrics). Lithic refitting, which is a pivotal method in taphonomical analysis of archeological levels, was not tested due to the low refitting potential of this material and, more particularly, the lack of any obvious raw material aspects that could help group products removed from the same pebble.

2.3.1. Size composition Artifact size composition has been shown to be an effective method for identifying the hydraulic transport of the artifacts and resulting sorting (Schick, 1986; Bertran et al., 2012). This method assumes that (a) knapping and tool use occurred on site, such that the size distribution of the archeological assemblage is comparable with results from experimental knapping, and (b) hominin activity (i.e., the import or export of lithic artifacts) had little impact on the size distribution of the material. For statistical reasons, archeological assemblages comprising less than 50 artifacts were excluded.

Meshes are often used to measure the maximum width of archeological pieces (Schick, 1986; Bertran et al., 2012). However, this method is inappropriate for the Shungura material, as $99 \%$ of artifacts range between 5 and $28 \mathrm{~mm}$ in width (Fig. 7). In order to ensure maximum accuracy, we measured each artifact, separating the material into three classes. Size limits were chosen in order to

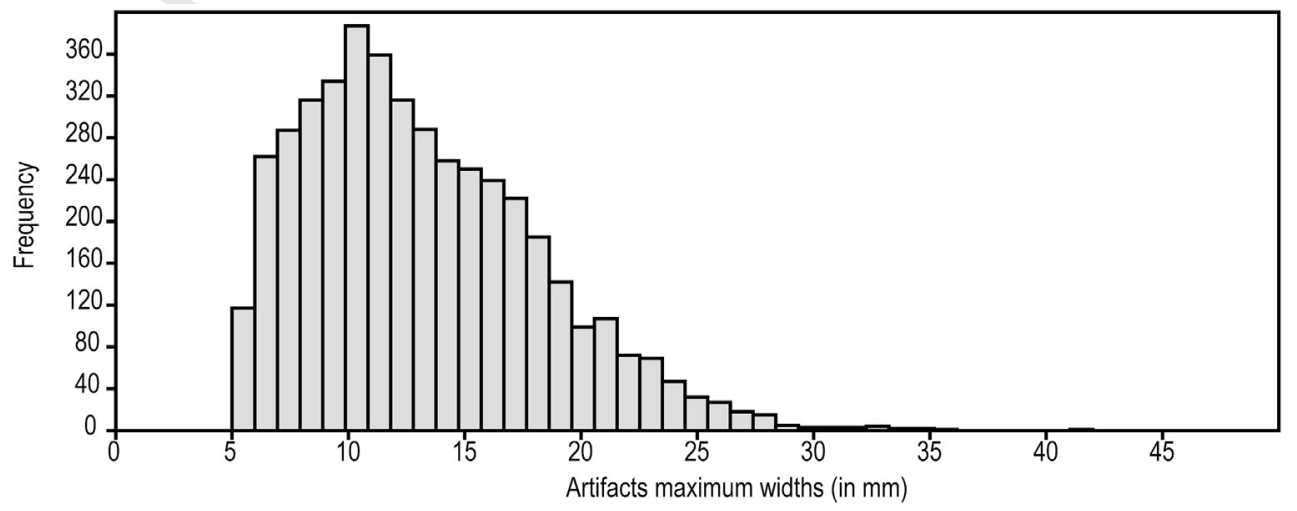

Figure 7. Distribution of artifact widths ( $\mathrm{mm}$ ). Only the artifacts $>5 \mathrm{~mm}$ in width were measured.

Please cite this article in press as: Maurin, T., et al., Early hominin landscape use in the Lower Omo Valley, Ethiopia: Insights from the taphonomical analysis of Oldowan occurrences in the Shungura Formation (Member F), Journal of Human Evolution (2017), http:// dx.doi.org/10.1016/j.jhevol.2017.06.009 
obtain classes with approximately equal numbers of artifacts (5-10 mm: $n=1619,11-15 \mathrm{~mm}: n=1330$, and $>15 \mathrm{~mm}: n=1203)$.

Experimental assemblages were produced by five knappers, one skilled knapper (M. Brenet) and four novices (D. Seifu, K. Kero, W. Amerga, and D. Kai), in 2010 and 2011 as part of the OGRE project. Each participant was asked to produce artifacts with sharp edges using the two techniques observed in the Shungura assemblages: bipolar percussion on an anvil and direct freehand percussion using a hard hammer (Merrick et al., 1973; Chavaillon, 1974; Ludwig, 1999; de la Torre et al., 2004). Quartz pebbles collected from paleochannels of the Omo River served both as raw materials and hammerstones. Twenty-one pebbles were knapped by bipolar percussion and 16 by freehand direct percussion, resulting in 3064 artifacts equal to or greater than $5 \mathrm{~mm}$ (Fig. 8, SOM Fig. S2). These experimental assemblages were subsequently used to investigate theoretical size distributions of assemblages resulting from all stages of the reduction sequence.

2.3.2. Artifact abrasion We defined four classes of edge abrasion based on the visual inspection of 4583 artifacts (excavated and surface finds) based on commonly applied criteria (i.e., Burroni et al., 2002; Chu et al., 2015, Table 1). The first two classes, nonabraded (0) and little abraded (1), were combined, as the significance of class 1 for investigating fluvial transport of artifacts remains uncertain. In order to test macroscopic classifications of edge damage observed on archeological pieces,

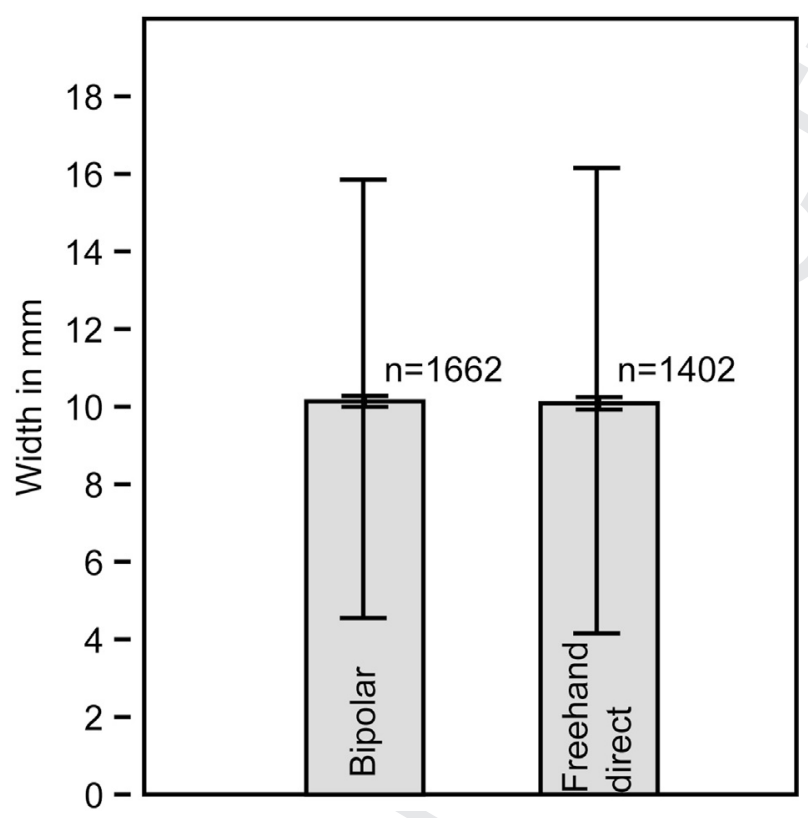

Figure 8. Mean artifact widths of the experimental assemblages. Differences in mean width of the two experimental assemblages are not statistically significant $(\mathrm{t}=-0.24624, p=0.81327)$. we used surface micrographs produced with a confocal laserscanning microscope held by the PACEA research unit at University of Bordeaux. A clear difference in intensity and distribution of surface alterations is evident in objects assigned to rank 0 and 3, with ranks 1 and 2 falling between the two. Differences are equally apparent when comparing non-abraded objects (rank 0) with the surface of fresh breaks. This is due to the two million years of post-depositional processes that have inevitably altered to some extent the archeological material (Fig. 9). 2.3.3. Bone abrasion Bones collected from OMO A42 were also analyzed in order to assess the degree of post-depositional surface modification. Despite strong post-exposure breakage due to modern weathering, an evaluation of bone roundness was possible after refitting fragments. When present, sandstone concretions were used to distinguish old from modern breakage due to weathering. In order to avoid biases connected to postdepositional fragmentation, the proportion of abraded to nonabraded bones was calculated from the total weight of each category rather than using the number of pieces. Numerous types of evidence for carnivore activity were also recorded, including digestion, gnawing, and tooth marks. While several marks could potentially relate to hominin activities, crocodiles, or other carnivores (Blumenschine et al., 1996; Njau, 2012), this was not investigated in detail due to the secondary nature of the deposit.

2.3.4. Orientation of lithic artifacts and bones Plans of J. Chavaillon's excavations at OMO A13 and those from H. Merrick's at OMO A16 were used to assess bone and lithic artifact orientations. Only one of the excavated horizons is represented, which explains the low number of artifacts for each occurrence compared to the number of pieces collected. OMO A13 is located in a silt layer eroding from a hillside, whereas the OMO A16 material comes from a sand layer exposed on a hillside. The two plans show the shape and orientation of both lithics and bones, which were integrated in GIS using ArcGIS 10.3 and QGIS 2.10.1. The maps were digitized and then georeferenced, using the vectorization tool of the ArcScan extension to automatically draw the pieces. The length and width axes were added manually following the general axis of the piece (SOM Fig. S3). Only pieces with an elongation index $>1.8$ (length/ width) were retained for analysis (Bertran and Texier, 1995). Due to the lack of data for artifact dip, the analysis was restricted to orientation only (Dechant Boaz, 1994; Benito-Calvo and de la Torre, 2011). Rose diagrams were generated using the Orientation Analysis Tools add-in in ArcGis (Kociánová and Melichar, 2016), and preferential orientation was tested using circular statistics according to Curray (1956).

\section{Results}

\subsection{Size composition of the assemblages}

Assemblages produced by both percussion techniques (direct and bipolar) are dominated by small artifacts (width $=5-10 \mathrm{~mm}$,

Table 1

Classes of edge damage.

\begin{tabular}{|c|c|c|c|}
\hline Range & Name & Description & Possible processes involved \\
\hline 0 & Non-abraded & All the edges appear fresh & - \\
\hline 1 & Little abraded & One or several lightly abraded edges & $\begin{array}{l}\text { Use (Merrick, 1976), limited water transport (Petraglia and Potts, 1994), } \\
\text { soil polish (Plisson and Mauger, 1988), trampling (Flenniken and Haggarty, 1979; } \\
\text { Courtin and Villa, 1982) }\end{array}$ \\
\hline 2 & Abraded & $\begin{array}{l}\text { Several abraded edges, crushing of edges, and } \\
\text { dorsal ridges }\end{array}$ & $\begin{array}{l}\text { Fluvial transport (Petraglia and Potts, 1994), soil polish (Plisson and Mauger, 1988), } \\
\text { trampling (Flenniken and Haggarty, 1979; Courtin and Villa, 1982) }\end{array}$ \\
\hline 3 & Highly abraded & $\begin{array}{l}\text { All edges and dorsal ridges are heavily abraded, } \\
\text { producing a 'rounded' artifact }\end{array}$ & Long distance fluvial transport (Petraglia and Potts, 1994) \\
\hline
\end{tabular}



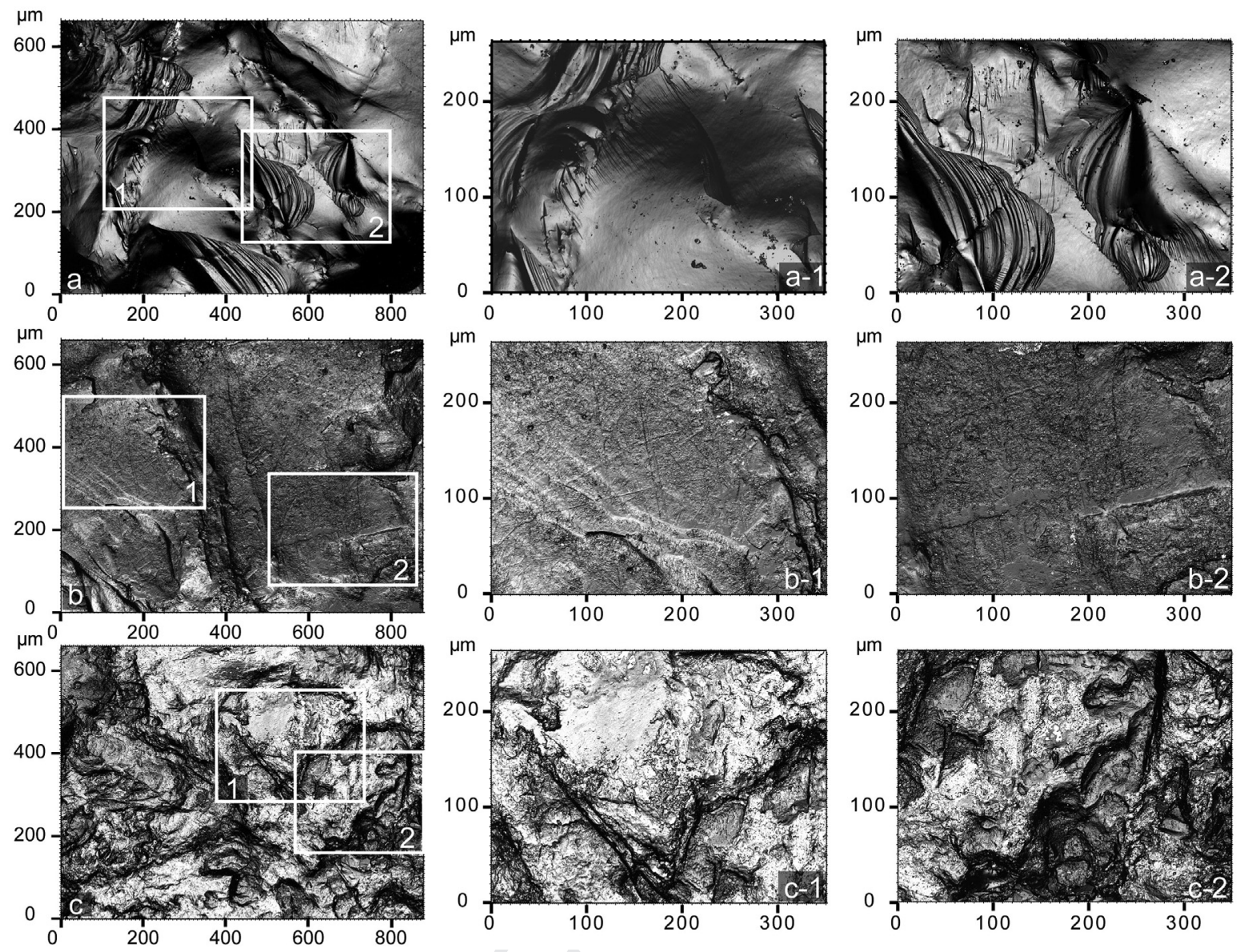

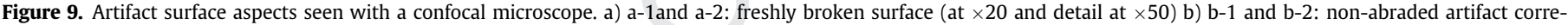
sponding to range 0 . c) c- 1 and c-2: highly abraded artifact corresponding to range 3.

Fig. 10a). Comparisons between experimental and archeological assemblages point to an overall deficit in smaller pieces in the latter. This winnowing of Oldowan assemblages induces a highly significant difference between the mean width of experimental (width mean $=10.1 \mathrm{~mm}$ ) and archeological data (width mean $=13 \mathrm{~mm} ; \mathrm{t}=22.527, p=6.7273^{-109}$ ).

3.1.1. Influence of topography The size of the smallest class (width between 5 and $10 \mathrm{~mm}$ ) is strongly dependent on modern topography (Fig. 10b). Overland flow eroding the slopes and hilltops significantly reduced the number of small artifacts, probably due to the selective transport of the lightest pieces away from the outcrops. In addition, artifacts found lying directly on exposed tuffs likely correspond to lag deposits. Consequently, material from these contexts (highly eroded slopes and lag deposits) was excluded from our size composition analysis. Therefore, assemblage compositions were compared only between occurrences with similar preservation conditions.

3.1.2. Influence of sedimentary context Overall, the assemblages from fine grained sediments contain at least 35\% of small (width $=5-10 \mathrm{~mm}$ ) and 35\% of medium-sized artifacts (width = 11-15 mm, Fig. 11). Assemblages from excavations at OMO A13 and $\mathrm{OMO} \mathrm{A} 2$ are comparable to experimental assemblages composed of approximately 70\% small artifacts (OMO A13: 68\%, OMO A2: 67\%). In contrast, the OMO A13 surface assemblage is significantly depleted in small pieces, either due to incomplete artifact recovery or erosion. Therefore, we can assume that other surface assemblages, such as OMO A29 and OMO A82 that are similar to the OMO A13 surface assemblage, originate from in situ occurrences with limited or no size sorting.
Assemblages found in sandy sediments are more heterogeneous. OMO A16 (excavation) and OMO A32 (scraped and sieved surface sediment) are only slightly depleted in small artifacts compared to the experimental series. This indicates little postdepositional winnowing and strongly suggests that these occurrences were close to the original occupation (Schick, 1986). Other assemblages contain considerably less small- and medium-sized artifacts, indicative of varying degrees of hydraulic sorting. These occurrences likely represent secondary artifact accumulations in channel deposits some distance from the original occupation.

3.1.3. Relation between assemblage richness and artifact size composition In both loamy and sandy sediments, the richer the assemblage, the higher the proportion of small artifacts (width $=5-10 \mathrm{~mm}$, Fig. 12). This pattern suggests that only the richest assemblages correspond to original knapping sites characterized by a very high proportion of small by-products.

Half of the small assemblages ( $n=5$, less than 50 artifacts) were found within sand deposits and therefore reflect secondary accumulations. Alternatively, we cannot exclude the possibility that small assemblages recovered from loamy sediments represent very brief, small-scale primary occupations.

\subsection{Artifact abrasion}

Surface finds do not show a higher proportion of edge damage compared to excavated artifacts, indicating edge abrasion to be unconnected to recent weathering (Fig. 13a). Furthermore, no correlation between size and abrasion was noted (Fig. 13b). All 
a

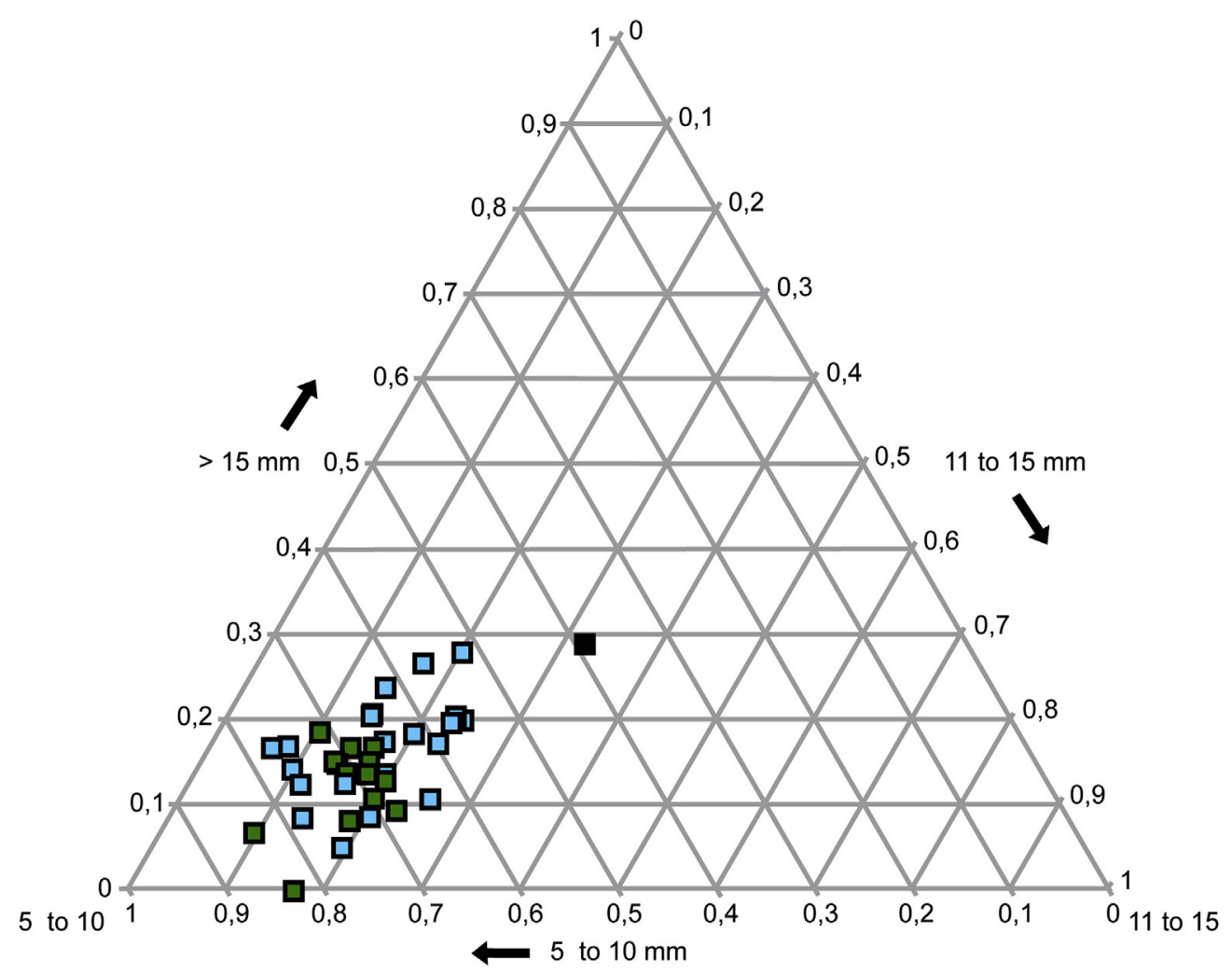

b

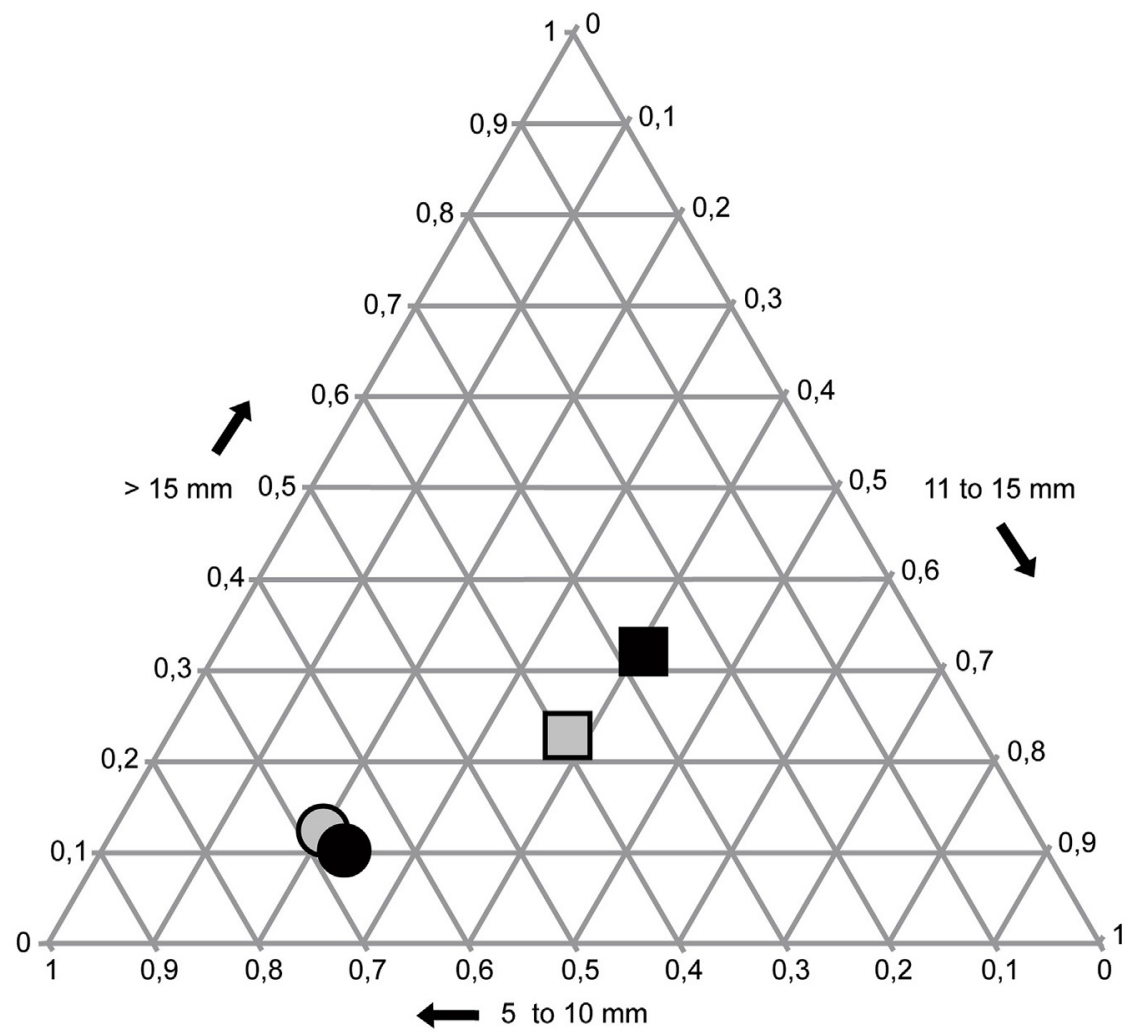

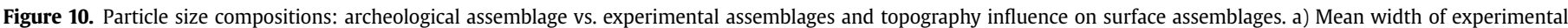

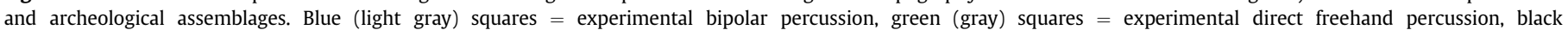

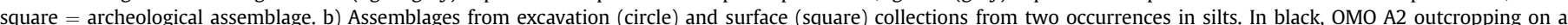

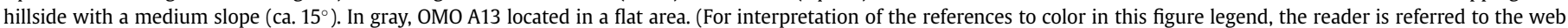
version of this article.)

Please cite this article in press as: Maurin, T., et al., Early hominin landscape use in the Lower Omo Valley, Ethiopia: Insights from the taphonomical analysis of Oldowan occurrences in the Shungura Formation (Member F), Journal of Human Evolution (2017), http:// dx.doi.org/10.1016/j.jhevol.2017.06.009 


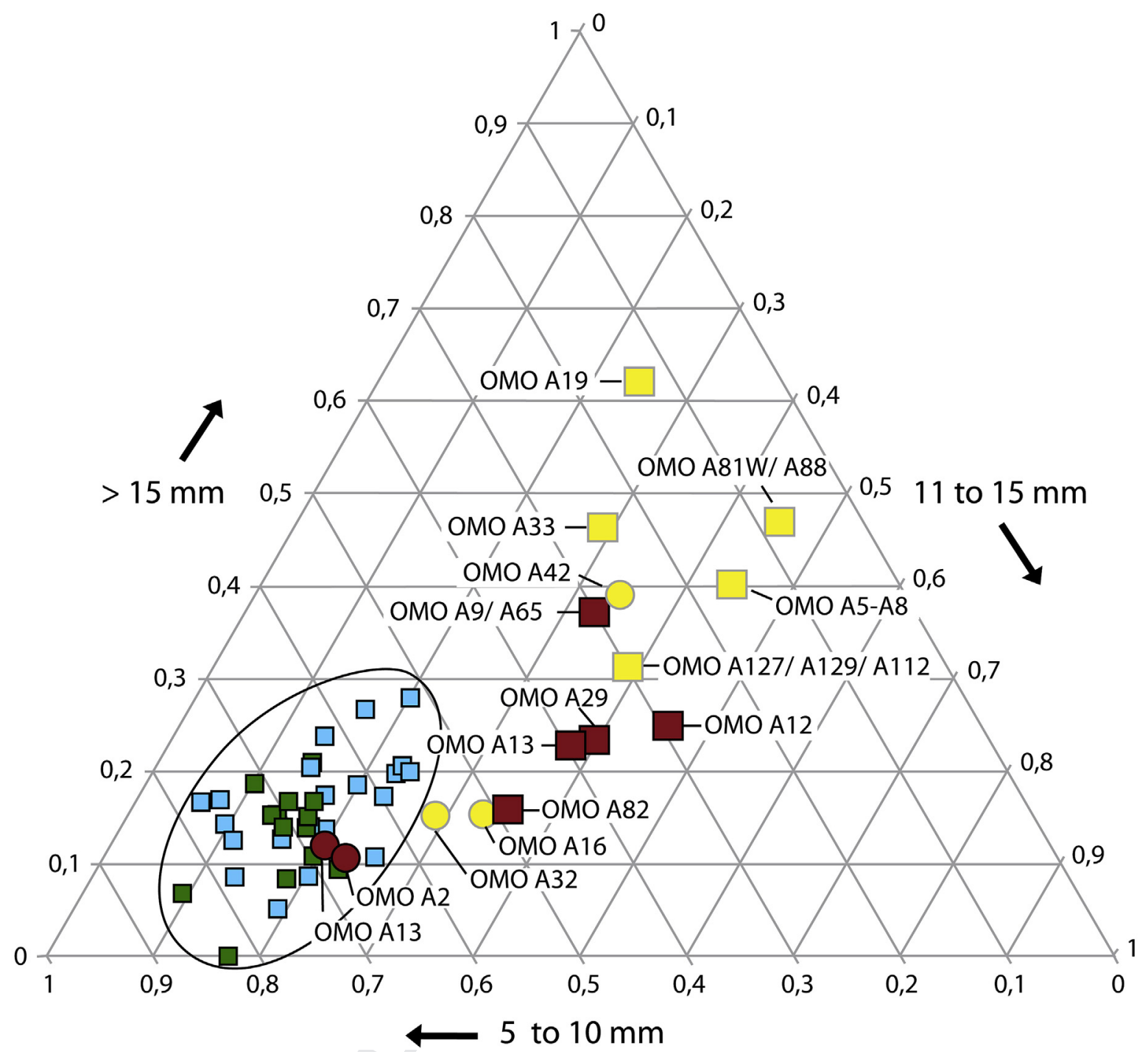

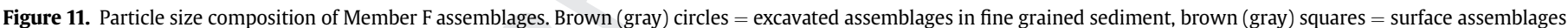

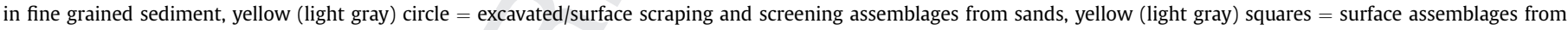

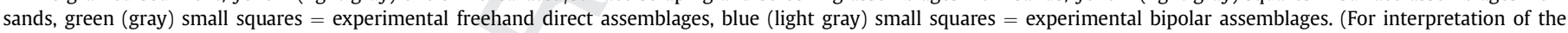
references to color in this figure legend, the reader is referred to the web version of this article.)

assemblages, whether from sands or fine-grain sediments, comprise predominately non-edge damaged and slightly abraded pieces, which account for approximately $86 \%$ of the material. This points to a generally good preservation of the artifacts in Member $F$ and suggests that most pieces were not subject to prolonged fluvial transport. However, the proportion of artifacts with postdepositional surface modifications (abraded/highly abraded edges) is by no means insignificant, with most assemblages incorporating small amounts of rounded, intrusive pieces. This proportion clearly differs according to the nature of the host sediment (Fig. 13c). Artifacts with highly abraded edges are more common in assemblages from sandy units representing channel fill $(3.7 \%$ in sands versus $1.4 \%$ in silts), whereas moderately abraded pieces are slightly more abundant in assemblages from fine-grained floodplain units (12.5\% in silts versus $9.9 \%$ in sands).

In fine-grained sediments, the proportion of post-depositional surface modification is almost identical for seven out of the nine assemblages selected for analysis, suggesting a broadly similar taphonomic history. In sands, the edge preservation is more heterogeneous. Although found in a coarse sand deposit, the assemblage from OMO A18 shows the lowest amount of abraded pieces among all assemblages (Fig. 14).

\subsection{Bone abrasion}

Bones collected from OMO A42 comprise a mix of rolled $(9.14 \%$, $n=1829$ ) and non-rolled elements (SOM Fig. S4). Rolled bones and bone fragments have smaller dimensions than non-rolled specimens (mean width of rolled bones/fragments $=10.2 \mathrm{~mm}$, mean width of non-rolled bones/fragments $=21.7 \mathrm{~mm} ; \mathrm{t}=10.534$, $p<0.0001$ ). Only ca. $5 \%$ (by weight) of non-rolled bones preserve post-depositional traces, including traces of digestion, gnawing, perforations, and incisions, indicating their rapid burial after deposition on the riverbed.

\subsection{Orientation of lithic artifacts and bones}

3.4.1. OMO A13 (fine-grained sediment) Among the 468 mapped artifacts, 139 elongated pieces were found outside desiccation cracks (Fig. 15). The rose diagram suggests a preferential orientation 


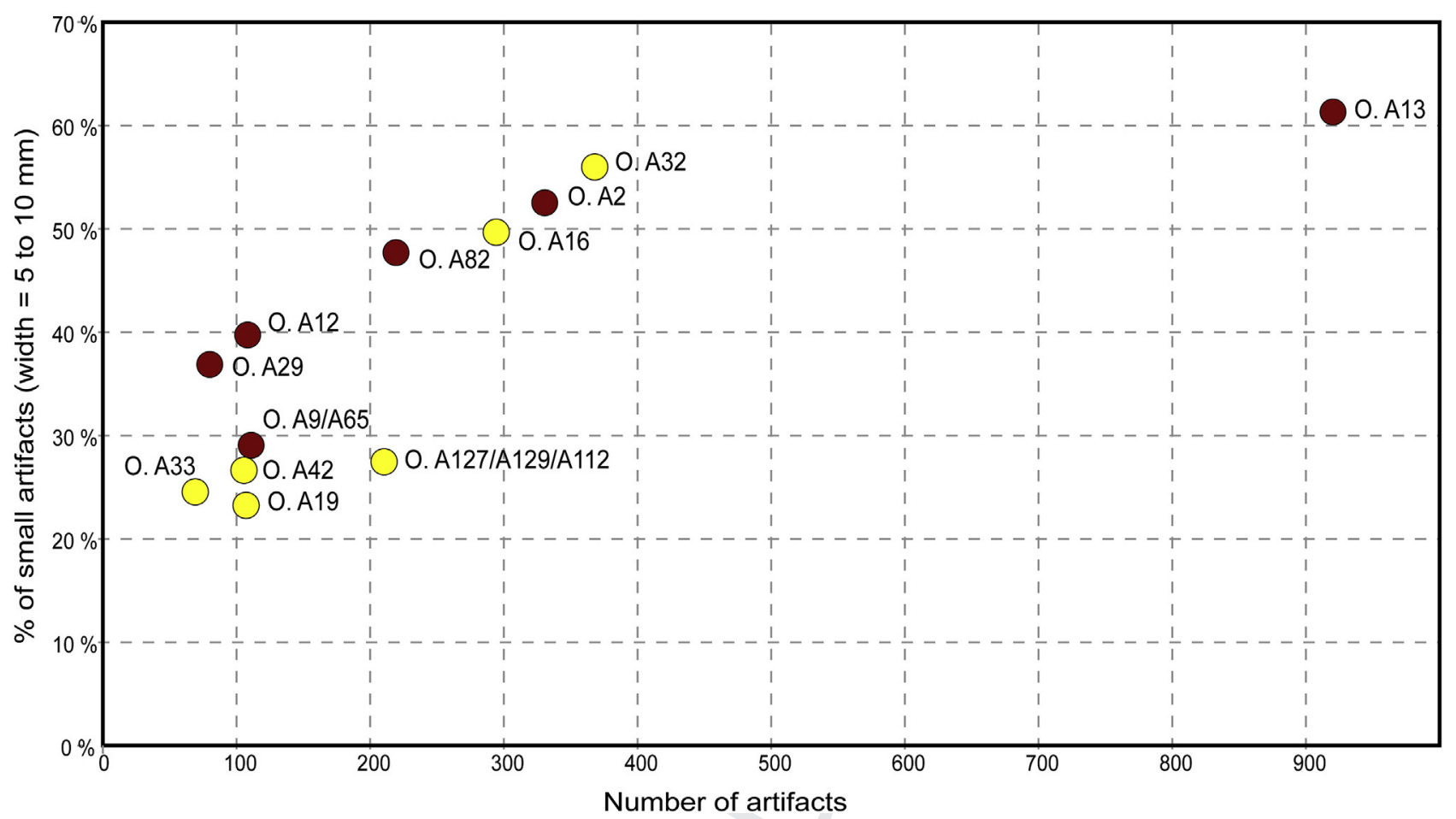

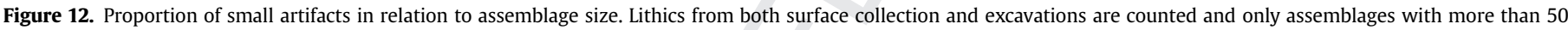

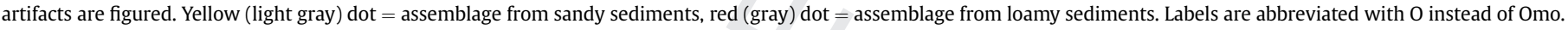
(For interpretation of the references to color in this figure legend, the reader is referred to the web version of this article.)

of objects along a NW-SE axis, alongside a less well expressed transverse axis. A Rayleigh test (Curray, 1956) confirms this pattern to be statistically significant ( $\mathrm{L}=33.24 \%, p<0.001$ ), although the intensity of the preferred orientation remains moderate.

3.4.2. OMO A16 (sands) Among the 89 bones and artifacts excavated, only 34 are sufficiently elongated for fabric analysis (Fig. 16). Although the total number of elongated pieces is low and just under the acceptability range for statistical analysis (Lenoble and Bertran, 2004), the rose diagram strongly suggests a well developed bimodal fabric typical of fluid flow (Sedimentary Petrology Seminar, 1965; Rust, 1972).

\section{Discussion}

4.1. The finer the sediments, the better the preservation (in most cases)

Not surprisingly, size composition, as well as lithic and bone surface modifications, point to significant variation in assemblage preservation. Particle size distribution indicates differences in lithic assemblage integrity to be related to the nature of the sediments. The size compositions of the two excavated assemblages (OMO A13 and OMO A2) are similar to the experimental assemblages, suggesting a lack of size sorting by stream flow. OMO A29 and OMO A82 appear equally well preserved, despite a moderate reduction in the proportion of small pieces that is likely due to the surface position of these occurrences. Unexpectedly, fabric analysis of OMO A13 reveals a preferential orientation of the artifacts, strongly suggesting post-depositional reworking of the archeological level. With that said, the absence of size sorting indicates stream flow to have had little impact on assemblage integrity. These four assemblages therefore reflect primary artifact accumulations rather than secondary concentrations of transported artifacts. On the other hand, observations by J. Chavaillon during excavations at OMO A13 identified the vertical movements of artifacts, that are often lodged in desiccation cracks (SOM Fig. S5) present in fine-grained sediments. This type of displacement is well known for clayey (vertic) soils that formed in tropical climates with marked seasonal contrasts (Wood and Johnson, 1978; Delagnes et al., 2006) and accounts for the vertical dispersion of artifacts to a depth of approximately $30 \mathrm{~cm}$ within the archeological levels (Chavaillon, 1974).

Despite evidence for well preserved assemblages in fine grained sediments, artifacts with abraded or highly abraded edges are nevertheless present, ranging between 3.4 and 22.3\%. Slight edge abrasion observable on quartz artifacts (class 1 ) is potentially attributable to an array of factors, including intensive use by hominins (Merrick et al., 1973), pedogenesis (Plisson and Mauger, 1988), and especially the shrinking and swelling of clays. Heavily abraded lithic artifacts undoubtedly result from other processes, most likely hydraulic transport of a significant duration (Levi-Sala, 1988). In this sense, abraded artifacts provide evidence for the introduction of a small amount of unrelated material by fluvial dynamics. Similar proportions of abraded artifacts in silty sediments were observed in other eastern African Oldowan sites, such as Kanjera South, where around $12 \%$ of the quartz and quartzite artifacts exhibit rounded edges and/or a glossy appearance (Lemorini et al., 2014).

In sandy sediment, the proportion of small artifacts (width $=5-10 \mathrm{~mm}$ ) is generally low, indicating hydraulic sorting, except at OMO A32 and OMO A16. Both sites have been interpreted as being close to the original occupation (Schick, 1986) insofar as they lack clear evidence of fluvial winnowing. These occurrences, located in a sandy layer corresponding to point bar deposits, are interpreted as having been quickly buried by floods. It should be noted that these occurrences are better preserved than several occurrences from loamy sediments. Six assemblages (OMO A19, OMO A33, OMO A42, 
a

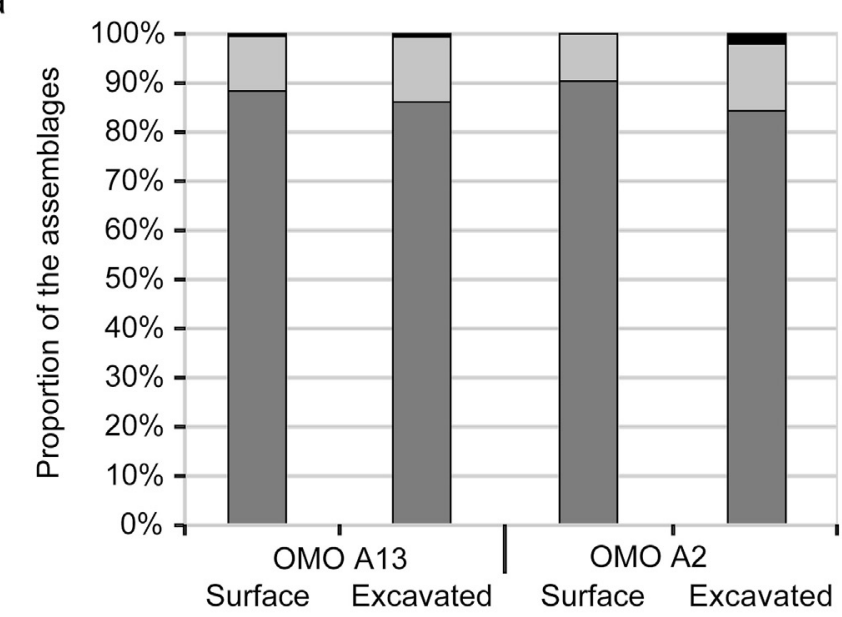

Edge abrasion of artifacts

-3 (Highly abraded)

$\square 2$ (Abraded)

$\square$ 0-1 (Little/non- abraded)

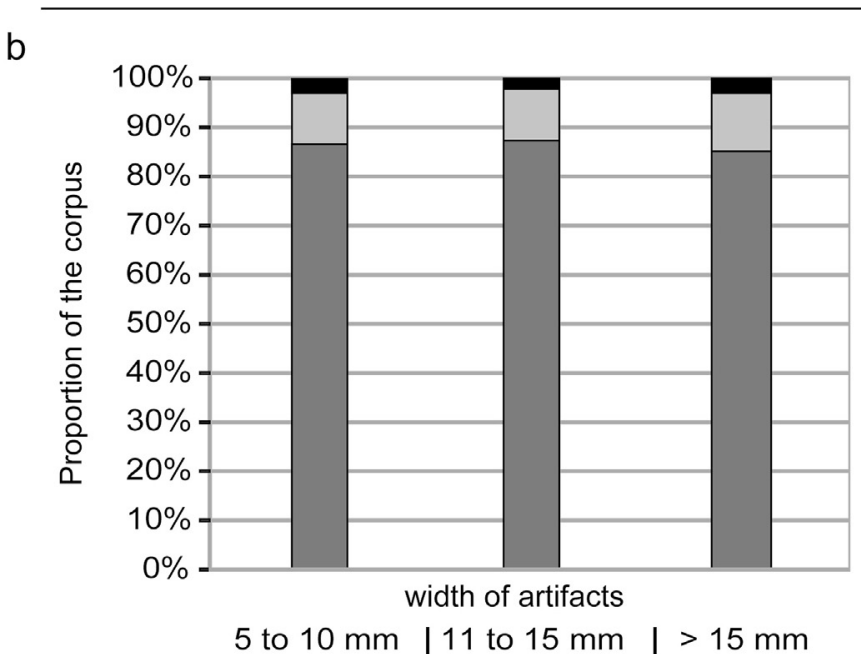

C

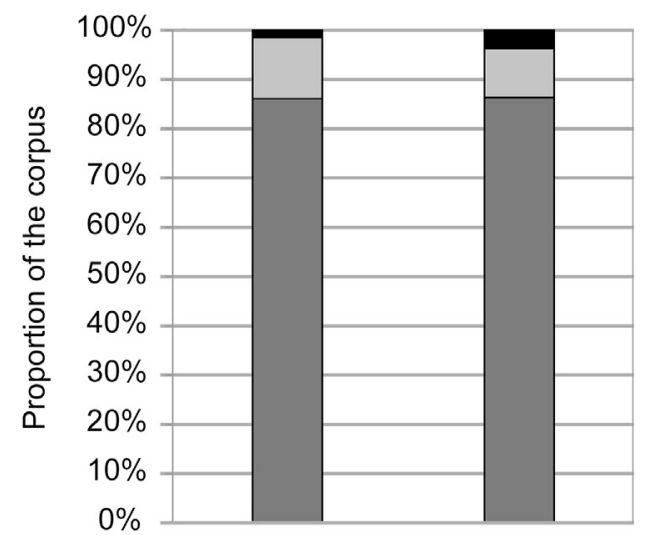

fine sediments | sandy sediments

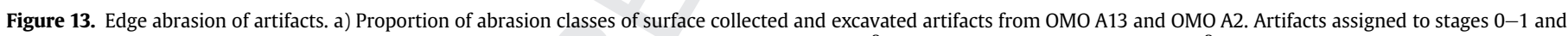

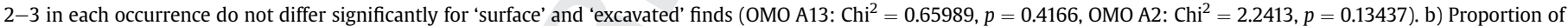

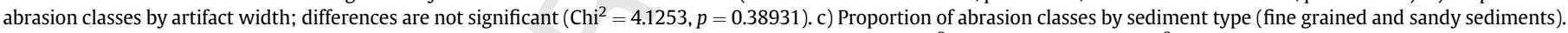
The proportion of highly abraded and abraded artifacts differ significantly according to the sediment $\left(\mathrm{Chi}^{2}=27.199, p=1.241^{*} 10^{-6}\right)$.

OMO A127/A129/A112, OMO A81W/A88, OMO A5-A8) also show a significant over representation of larger artifacts (width $>15 \mathrm{~mm}$ ). Additional evidence for assemblage modification by stream flow can be seen in the bimodal fabrics at OMO A16, which is typical of fluvial transport (Sedimentary Petrology Seminar, 1965; Rust, 1972), combined with high (although variable) amounts of heavily abraded lithics and rolled bones and bone fragments. Taken together, this indicates the mass transport of material as channel bedload. Mixing of both non-rolled and rolled bones suggests variable burial rates in sandy point bars, as previously identified in taphonomic analyses of members C, E, and F (Dechant Boaz, 1994). OMO A19, OMO A33, OMO A42, and OMO A127/A129/A112 therefore represent mixed archeological material re-deposited in a channel context following fluvial erosion. As such, the reliability of a primary association of lithic and bone material cannot be established within any certainty.

\subsection{Two artifact horizons, one episode of deposition}

Fine grained archeological layers are usually $30-50 \mathrm{~cm}$ thick, as at OMO A13, for example (Chavaillon, 1976), and more generally in the OMO 123 complex (Fig. 4). This thickness is assumed to result from post-depositional scattering of artifacts due to the shrinking and swelling of the clay-rich sediments rather than indicating several occupations.

Archaeological material is often recovered from both fine grained and sandy layers, as at OMO 1/E, OMO 123, and OMO 79. As a rule, isolated archaeological occurrences are always located 2-3 $\mathrm{m}$ above the artifact bearing sand layer in a given complex. Although spatially close, both types of artifact occurrences are never found immediately superimposed but are laterally offset by several dozen to several hundred meters. This strongly suggests they derive from a single occupation event, which was subsequently redistributed by fluvial dynamics as meanders shifted across the floodplain (see Figs. 17 and 18 for an interpretation of OMO 79). This process can be explained by the following five-phase scenario: (1) hominin settlement in a meander of the floodplain; (2) shifting of the meander (i.e., erosion of the concave bank and deposition on the convex bank, progressively forming stacked bowlike sand bodies); (3) erosion of part of the settlement and subsequent redistribution of the artifacts in the channel, thus forming a series of secondary artifact concentrations depicting increasing downstream hydraulic sorting (see Schick, 1986), occasional floods may also transport some artifacts across the floodplain; (4) meander cut-off and abandonment of the old river bed; and (5) progressive burial by overbank silts of the occupation and the 


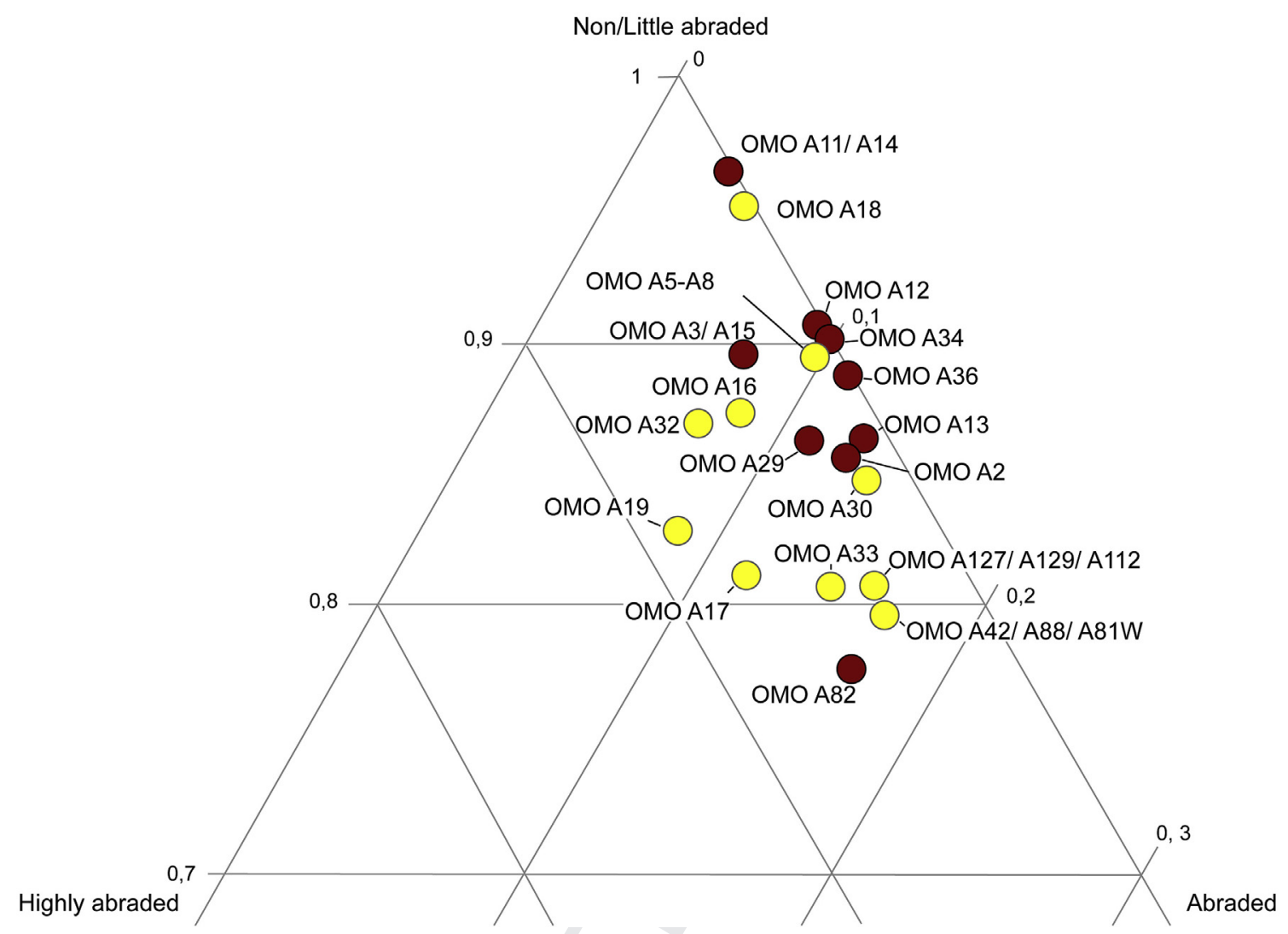

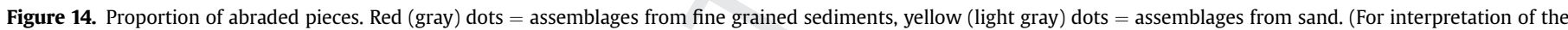
references to color in this figure legend, the reader is referred to the web version of this article.)

redistributed artifact concentrations. In this scenario, occurrences in sandy sediments depicting a low depletion of small artifacts and limited edge abrasion (OMO A18, OMO A16, and OMO A32) reflect quickly buried point bar occupations. Detailed reconstruction of the direction of hydraulic redistribution was unfortunately impossible due to the extremely irregular surface of the outcrops, the highly sinuous paleomeanders, and difficulties in determining the mean flow direction at the scale of the archeological complex from available measurements.

\subsection{Environmental context of the archeological occupation within Member $F$}

Faults, gullies, and the massive nature of most floodplain deposits preclude reliable stratigraphic correlations between the archeological complexes of Member F. Moreover, as shown in the composite model for OMO 1/E (Fig. 5), the sand lenses are not reliable stratigraphic markers for broad correlations across the entire Shungura Formation. To overcome this difficulty, the vertical position of occurrences relative to Tuff $\mathrm{F}$ and a well developed dark grayish-brown vertic paleosol with abundant nodular $\mathrm{CaCO}_{3}$ concretions (unit FF (P) on Figs. 3 and 5) was used to build rough correlations between archeological complexes. Both the tuff and paleosol can be followed between outcrops and are therefore reliable stratigraphic markers. Unfortunately, the paleosol is not observable everywhere in the northern part of the surveyed area, which is predominantly sandy (Ftji2, Ftji5, and FtJi 1-3-4).

Contrary to J. Chavaillon (1976), H. Merrick (1976), and C. Howell et al. (1987), who distinguished several small, repeated occupations within Member $\mathrm{F}$ based on discrete layers containing archeological remains, we suggest a single phase of occupation redistributed in several sedimentary layers within the three neighboring complexes of OMO 123, OMO 1/E, and OMO 79. This phase of occupation would be associated with the earliest depositional phase of Member F and, therefore, can be more reliably correlated with dates from the base (ca. $2.32 \pm 0.02 \mathrm{Ma}$ ) rather than the top (ca. $2.27 \pm 0.04 \mathrm{Ma}$ ). In FtJi2, FtJi5, and FtJi 1-3-4, the occurrences are found from the base (FtJi 5) to approximately $6 \mathrm{~m}$ above Tuff $\mathrm{F}$ and are related to occupation phases laid down early in the deposition of Member F. OMO 57, discovered by J. Chavaillon (1974), is also positioned in the lower part of Member F (Howell et al., 1987).

The scarcity of Oldowan occupations during the latter depositional stages of Member $F$ does not result from sampling bias as (1) the lower and upper parts of Member $F$ are equally exposed along the surveyed outcrops and (2) the whole sequence was intensively surveyed. Hominin remains show a similar pattern, being for now totally absent in the upper part of Member F, with at least 25 specimens of both gracile and robust australopithecines (de Heinzelin, 1983; Suwa et al., 1996) discovered in the lower part of Member F-excluding the materiel recovered within Tuff F (Fig. 19). This pattern does not necessarily suggest an absence of hominins during the deposition of the upper part of the sequence. It is simply consistent with the general distribution of paleontological remains in Member F: 2426 specimens were collected in the lower part of Member F, whereas only 72 specimens were recovered from the upper part.

The scarcity of sandy layers in upper Member $\mathrm{F}$, which is mainly composed of fine grained sediments, suggests that during this period the Omo River was situated outside the surveyed area due to the lateral migration of the fluvial system. Considering that a significant proportion of the artifacts from the lower part of Member $F$ are found in loamy deposits (sandy context: $n=2036$, loamy 


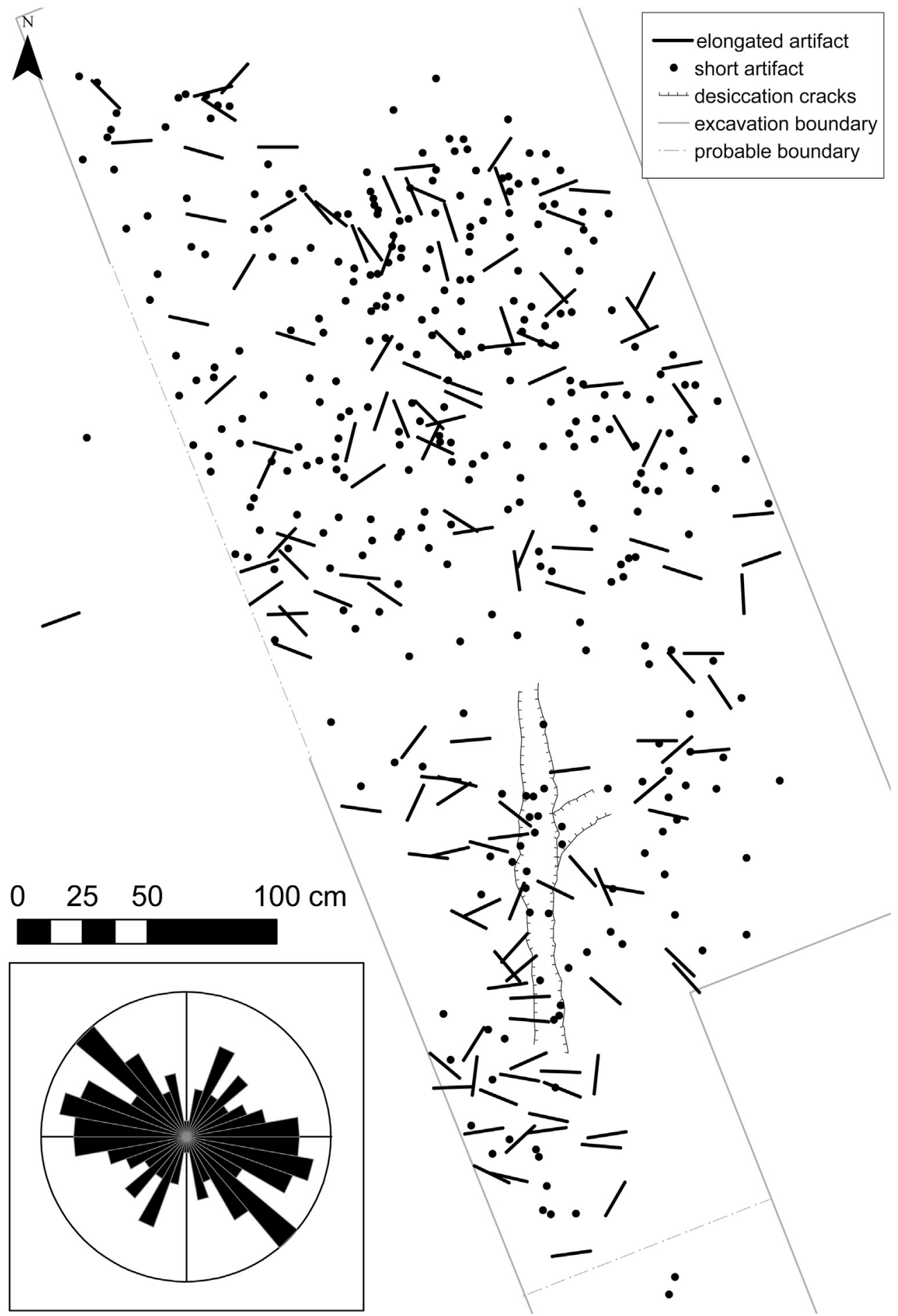

Figure 15. Planimetric map of OMO A13 and rose diagram showing the orientation of the elongated pieces (elongation index $>1.8$ ), redrawn after Chavaillon.

context: $n=2427$ ), the lack of archeological occurrences in the upper part of Member $\mathrm{F}$ cannot merely be interpreted as the consequence of a general over-representation of artifacts in secondary sandy deposits. Rather, this pattern might indicate that Oldowan toolmakers followed the migration of the river, preferring the vicinity of the river for carrying out their knapping activities. This hypothesis merits further testing across the entire Member $\mathrm{F}$ outcrops in the Shungura Formation.
The proximity of sites to water sources is typical of Oldowan sites (Plummer, 2005; Rogers and Semaw, 2009), having been previously documented at Gona, Middle Awash, Hadar, Lokalalei 1 and 2C, and Kanjera South. With that said, the Hadar occurrences are thought to reflect occupations in a mesial or distal floodplain, possibly close to a crevasse (Rogers and Semaw, 2009), which, if confirmed, would suggest some diversity in the environment of early hominin settlements. 


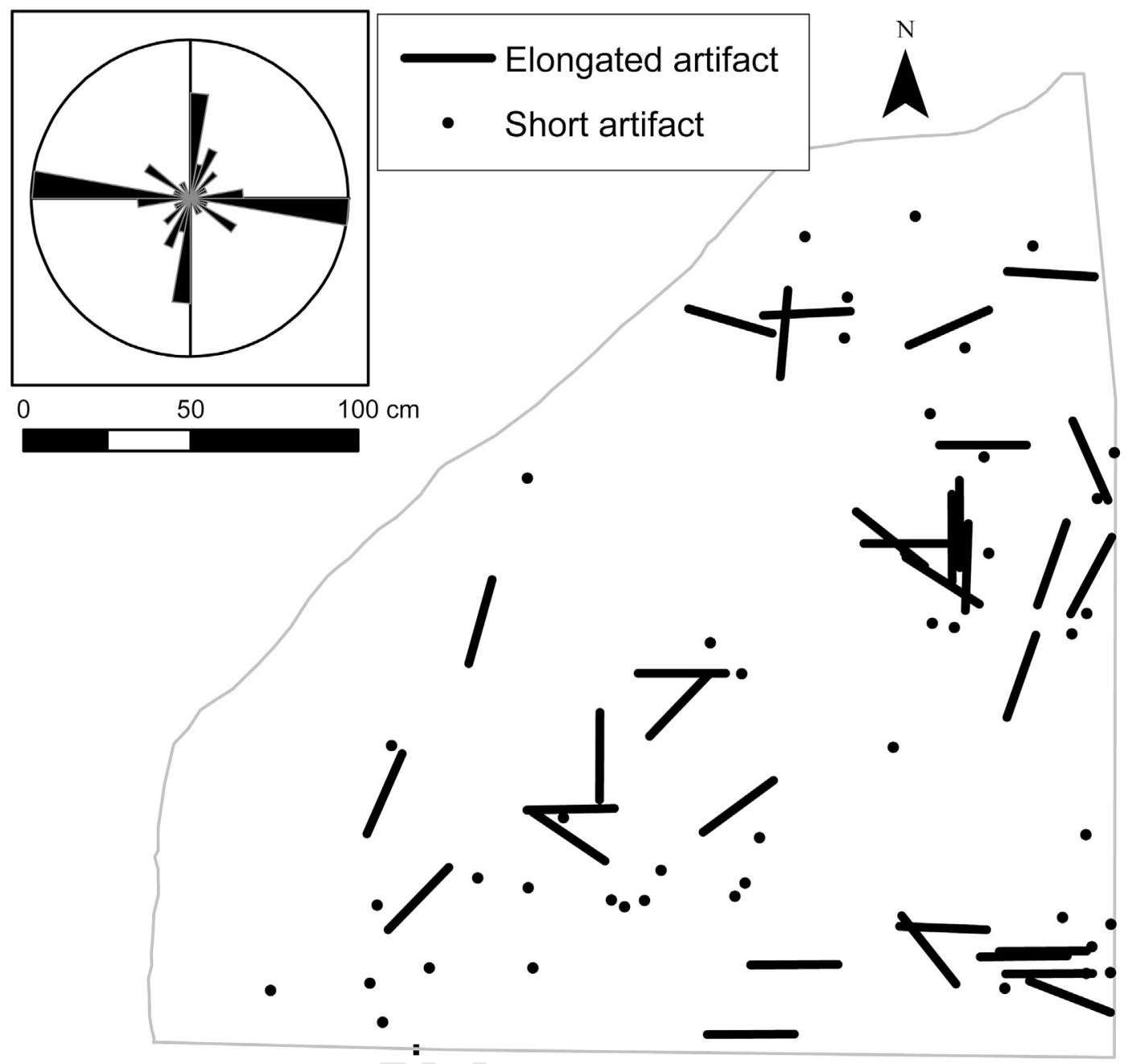

Figure 16. Planimetric map of OMO A16 and rose diagram showing the orientation of the elongated pieces, redrawn after H. Merrick and C. Howell.

\subsection{From more than 100 to less than 10}

A significant proportion of Member $F$ occurrences are interpreted as resulting from post-depositional artifact remobilization. This is clearly the case for the overwhelming majority of occurrences found in sandy sediments that reflect bedload material in channels. This would also hold true for most occurrences in fine grained sediments. Less dense occurrences close to richer, well preserved ones are assumed to correspond to secondary accumulations re-deposited by hydraulic transport. For example, OMO A12 and OMO A9/A65 could be interpreted as secondary concentrations eroded from OMO A13. Although not in primary position, OMO A12 nevertheless produced larger artifact numbers and a higher proportion of small- and medium-sized artifacts (5-15 $\mathrm{mm}$ in width) compared to OMO A9/OMO A65, which is located further south (SOM Table S1, Fig. 2). This pattern would therefore reflect a downstream gradient in assemblage integrity originating from the primary accumulation of OMO A13.

As a consequence, the hundreds of occurrences found in Member F likely reflect a much smaller number of primary occurrences, meaning that the abundance of findspots in the Shungura Formation does not reflect a genuine behavioral pattern characterized by the coexistence of large occupations and satellite activity sites as suggested for Koobi Fora (Isaac, 1981). Furthermore, most, if not all, of the small occurrences are secondary spots, redeposited from a larger initial occupation.
Among the 26 occurrences comprising more than 50 artifacts, four can be interpreted as primary depositional contexts in fine grained sediments (OMO A13, OMO A29, OMO A2, OMO A82), with two other assemblages considered to be in a secondary position (OMO A9/A65, OMO A12). Three occurrences in sands are interpreted to be in primary or sub-primary positions (OMO A16, OMO A18, OMO A32), whereas six assemblages in sand contexts are undoubtedly in a secondary position, having been transported a considerable distance as revealed by a high degree of size sorting (OMO A42, OMO A19, OMO A33, OMO A129/A127/A112, OMO A81W/A88, OMO A5-A8; Fig. 20). The position of eight other occurrences remains uncertain due to their unfavorable recovery context (i.e., highly eroded slope deposits).

This number of primary Oldowan occurrences, most likely less than 10 in the surveyed outcrops of Member F, appears similar to other pene-contemporaneous complexes, such as Gona (Semaw, 2000), Hadar (Kimbel et al., 1996), Lokalalei (Roche et al., 2003), Kanjera South (Plummer et al., 1999), as well as more recent Oldowan sites at Olduvai (Leakey and Clark, 1971), Koobi Fora (Harris, 1997), Peninj (de la Torre et al., 2003), Melka Kunture (Chavaillon and Piperno, 2004), or the Nyabusosi Formation (Pickford et al., 1989). Each complex would correspond to a single primary occupation redistributed into multiple well circumscribed secondary spots. When the total number of artifacts in each complex is taken into consideration, the entire assemblage appears numerically significant (OMO 123: $n=1838$, OMO 1/E: $n=612$, OMO 79: 
1

floodplain

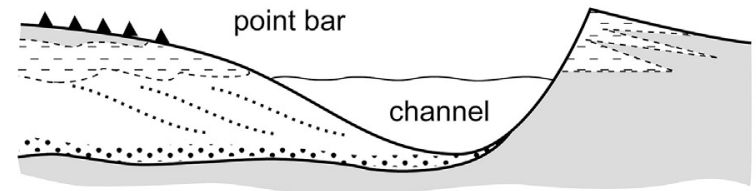

2

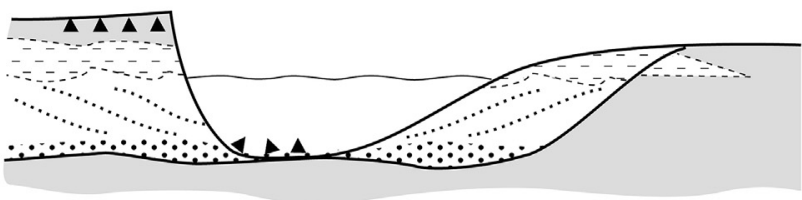

3

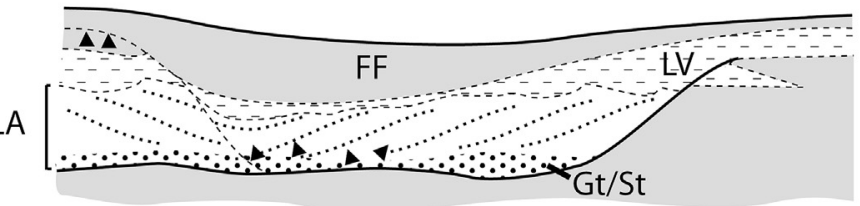

floodplain

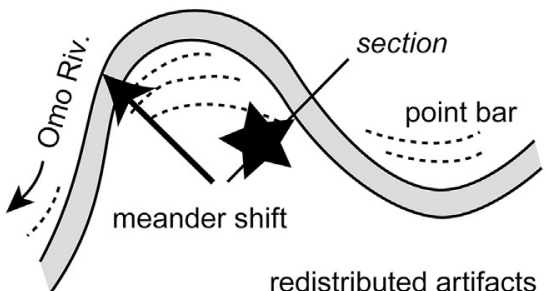

redistributed artifacts
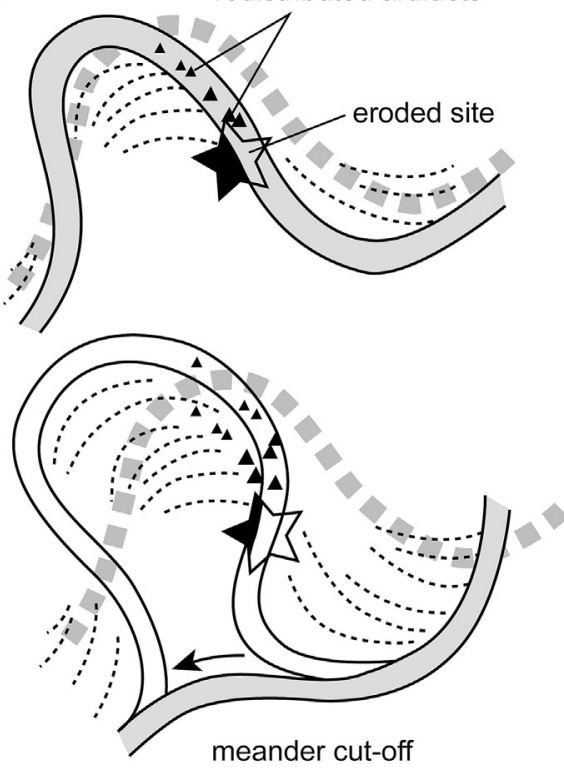

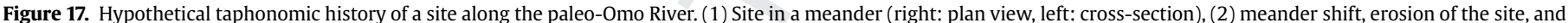

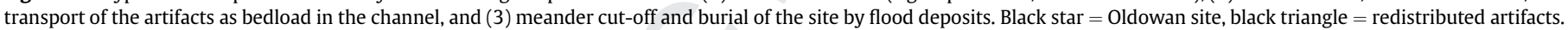

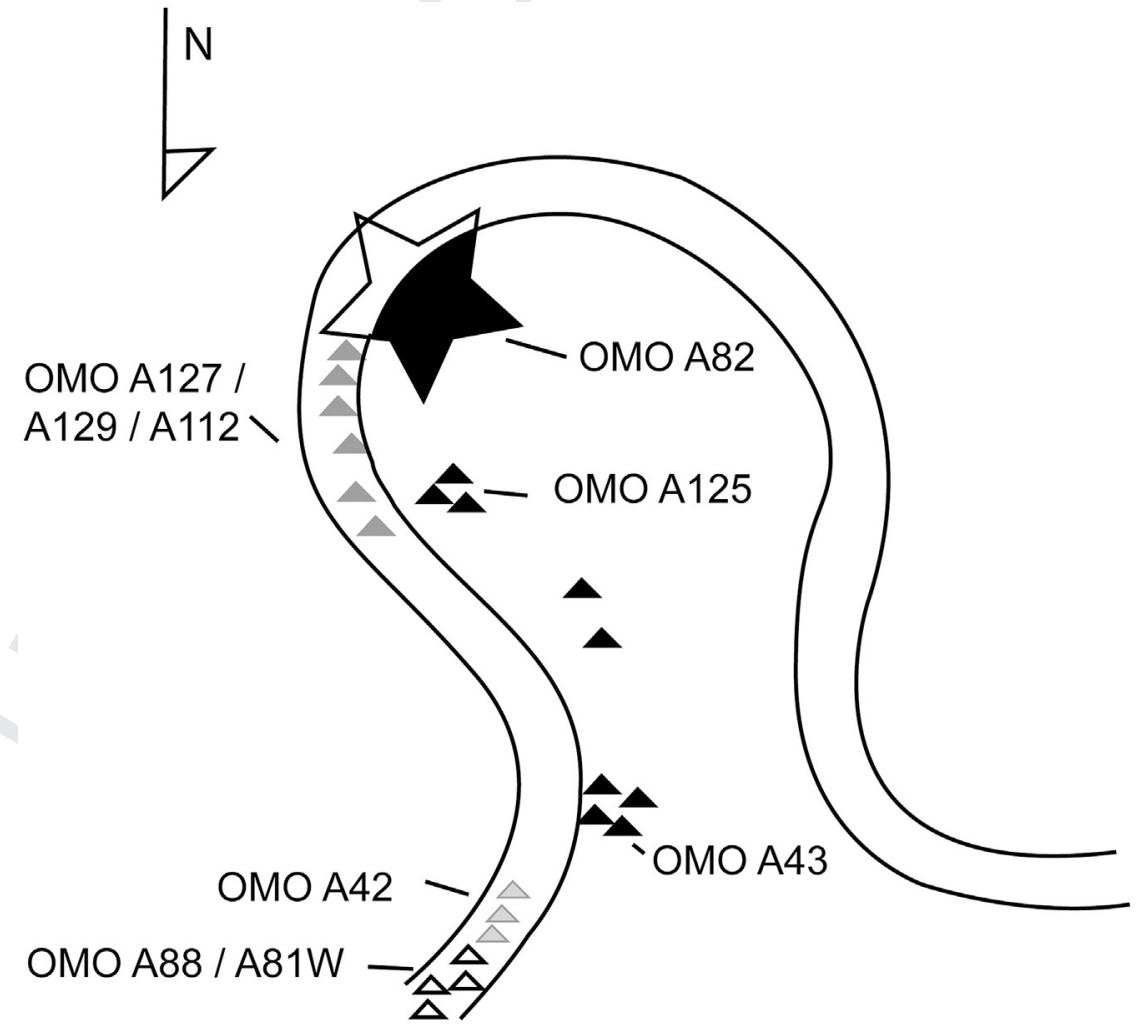

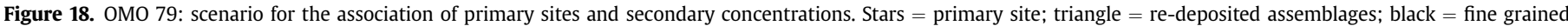

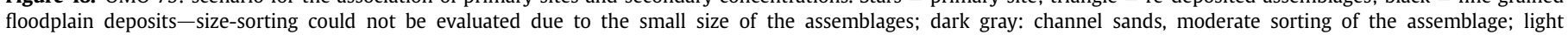
gray = channel sands, substantial size sorting of the assemblage; white = channel sands, artifact size-sorting could not be evaluated due to the presence of sandstone slabs.

Please cite this article in press as: Maurin, T., et al., Early hominin landscape use in the Lower Omo Valley, Ethiopia: Insights from the taphonomical analysis of Oldowan occurrences in the Shungura Formation (Member F), Journal of Human Evolution (2017), http:// dx.doi.org/10.1016/j.jhevol.2017.06.009 


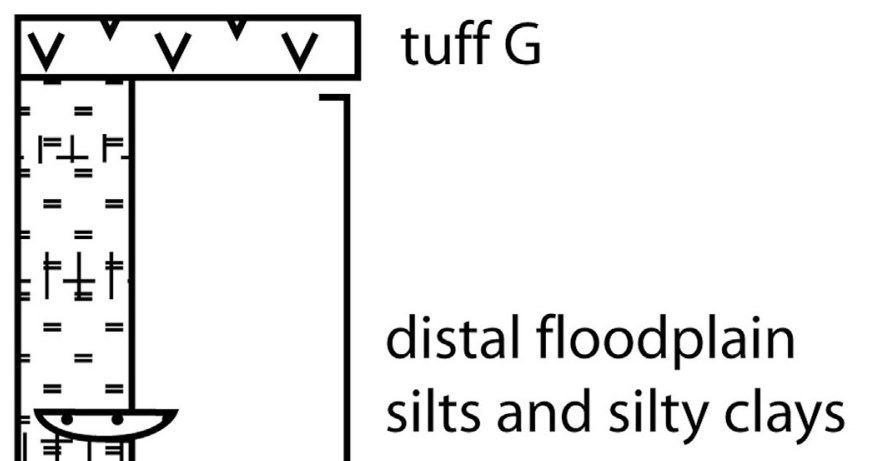

\section{channel sands and proximal floodplain silts}

$\Delta$ artifact occurrences $\mathrm{H}$ hominin remains

$n=775)$ and similar in size to assemblages recovered from Gona EG10 (Semaw, 2000), Hadar AL 894 (Hovers, 2009), Lokalalei 1 and 2c (Roche et al., 2003), and Kanjera South (Bishop, 2012).

\section{Conclusion}

We propose a new scenario of taphonomically induced spatial patterning for the archeological record of the Shungura Formation. Shifts in the meandering paleo-Omo River and repeated flooding scattered and redistributed (horizontally and vertically) the primary hominin occupations, which were originally limited to less than 10 occurrences in Member F. The multiple, small circumscribed occurrences documented in floodplain silts in close proximity (i.e., within a few hundred meters) to the primary occurrences do not reflect any underlying behavioral patterns. Rather, they result from the horizontal redistribution, hydraulic sorting and secondary concentration of artifacts by stream flow within each archeological complex. Several hundred thousand years later, normal faults due to rift tectonics cut the alluvial sequence into large blocks, exposing the artifact bearing deposits along multiple outcrops. Such a scenario rules out a spatial patterning that would reflect a complementarity between home bases and multiple small satellite sites, as proposed in other contexts and interpreted as mono-specific short-term occupations (Isaac, 1978).

Lateral shifts of the meandering paleo-Omo river across the floodplain might also be responsible for the redistribution of artifacts within sandy channels that eroded the primary settlements. The archeological occupation may therefore be limited to a single or a small number of occupation phases, mainly restricted to the lower part of Member F. The sites were located on riverbanks, on previous levees of the paleo-Omo River, and in nearby floodplain areas. This preference of the Omo toolmakers for riverine environments could explain the scarcity of archeological material in the upper part of Member $\mathrm{F}$ that comprises primarily distal floodplain sedimentary facies. The proximity to water is, however, only one aspect of hominin landscape use. These behaviors may equally have been conditioned by the regional availability of other biotic and abiotic resources such as flora, fauna, and raw materials that need to be explored by future analyses.

This scenario brings key insights for the spatial, temporal, and environmental distribution of the archeological occurrences and 

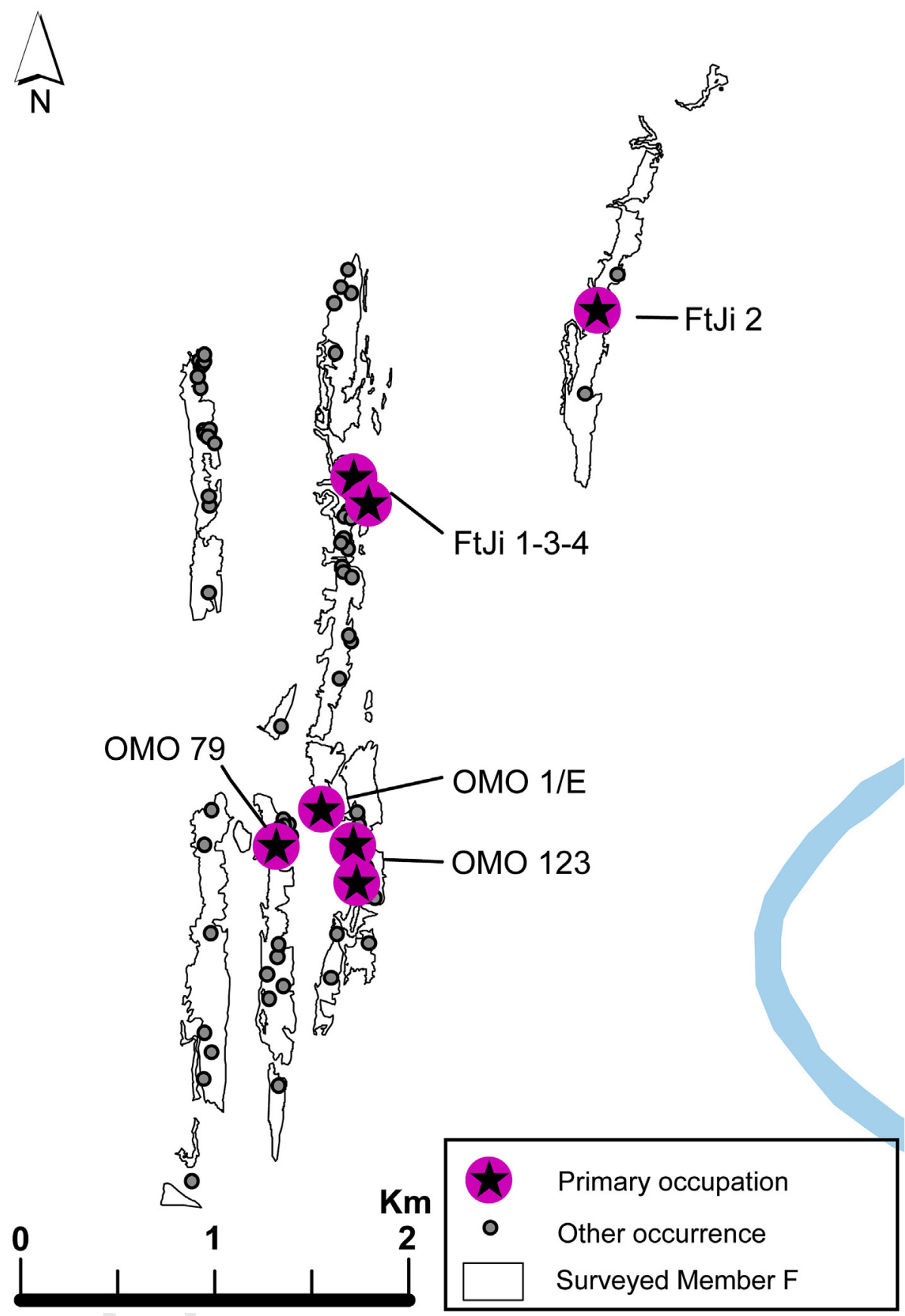

Figure 20. Inferred location of the primary occupations in Member F of the Shungura Formation.

related hominin land use behaviors in the Shungura Formation. The rich archeological record from Member $F$ would reflect one or a very limited number of occupation phases, structured in a few dense hominin settlements located in riverbank habitats in the lower part of Member F. Additionally, the taphonomically informed model proposed here could be useful for reevaluations of archeological site spatial patterning at micro-regional scale in other alluvial contexts regardless the period.

\section{Acknowledgments}

This research would not have been possible without the considerable amount of fieldwork undertaken by both the IORE and OGRE projects. We are particularly grateful to Florence Chavaillon, who provided one of us (AD) with all the field and research archives of her father, Jean Chavaillon. We have also benefited from access to Clark Howell's archives thanks to Tim White and the Human Evolution Research Center at the University of California, Berkeley (Antoine Souron, Eva Herbst, Kathryn Rieck, and Joshua Carlson). We would also like to thank Joséphine Lesur (Muséum National d'Histoire Naturelle, Paris) for her help in determining bone marks and Paul Haesaerts (Institut Royal des Sciences Naturelles de Belgique) for his precious help in the field. We are grateful to Michel Brenet (Institut National de recherches archéologiques préventives and PACEA/University of Bordeaux), Dawit Seifu, Kochito Kero, Waganu Amerga, and Daniel Kai who produced the experimental assemblages, and to Alain Queffelec (PACEA/University of Bordeaux) for the confocal surface micrographs. 
The OGRE project was granted a permit by the Authority for Research, Conservation and Cultural Heritage of Ethiopia (ARCCH). We would like to thank the personnel of the ARCCH, as well as the bureau of Culture of the Southern Nations, Nationalities and People Region, and the South Omo Zone. In particular, we warmly thank the ARCCH curators for their help with the collections housed in Addis Abeba.

\section{Funding}

The OGRE project received funding and logistical support from the Agence Nationale pour la Recherche (ANR-09-BLAN-0238 to M. Brunet), the Ministère des Affaires Étrangères et du Développement International (Sous-Direction de l'Enseignement supérieur et de la Recherche/Embassy of France to Ethiopia), the Foundation Fyssen, the Centre Français des Etudes Ethiopiennes, PACEA (CNRS/University of Bordeaux), IPHEP (CNRS/University of Poitiers), and the Centre National de la Recherche Scientifique. This work is part of a $\mathrm{PhD}$ dissertation (T. Maurin) funded by the LABEX LaScArBx (University of Bordeaux). LaScArBx is a research program supported by the ANR (ANR-10-LABX-52).

\section{Appendix A. Supplementary Online Material}

Supplementary online material related to this article can be found at http://dx.doi.org/10.1016/j.jhevol.2017.06.009.

\section{References}

Barsky, D., Chapon-Sao, C., Bahain, J.-J., Beyene, Y., Cauche, D., Celiberti, V. Desclaux, E., de Lumley, H., de Lumley, M.-A., Marchal, F., Moullé, P.-E. Pleurdeau, D., 2011. The Early Oldowan stone-tool assemblage from Fejej FJ-1A, Ethiopia. J. Afr. Archaeol. 9, 207-224.

Benito-Calvo, A., de la Torre, I., 2011. Analysis of orientation patterns in Olduvai Bed I assemblages using GIS techniques: Implications for site formation processes. J. Hum. Evol. 61, 50-60.

Bertran, P., Texier, J.-P., 1995. Fabric analysis: Application to Paleolithic sites. J. Archaeol. Sci. 22, 521-535.

Bertran, P., Lenoble, A., Todisco, D., Desrosiers, P.M., Sørensen, M., 2012. Particle size distribution of lithic assemblages and taphonomy of Palaeolithic sites. J. Archaeol. Sci. 39, 3148-3166.

Bishop, L.C., 2012. Behavioural variability in Oldowan hominins: the case from Kanjera South, Kenya. Quatern. Int. 279-280, 52.

Blumenschine, R.J., 2003. Late Pliocene HOMO and Hominid Land Use from Western Olduvai Gorge, Tanzania. Science 299, 1217-1221.

Blumenschine, R.J., Marean, C.W., Capaldo, S.D., 1996. Blind tests of inter-analyst correspondence and accuracy in the identification of cut marks, percussion marks, and carnivore tooth marks on bone surfaces. J. Archaeol. Sci. 23, 493-507.

Blumenschine, R.J., Masao, F.T., Tactikos, J.C., Ebert, J.I., 2008. Effects of distance from stone source on landscape-scale variation in Oldowan artifact assemblages in the Paleo-Olduvai Basin, Tanzania. J. Archaeol. Sci. 35, 76-86.

Blumenschine, R.J., Stanistreet, I.G., Njau, J.K., Bamford, M.K., Masao, F.T., Albert, R.M., Stollhofen, H., Andrews, P., Prassack, K.A., McHenry, L.J., FernándezJalvo, Y., Camilli, E.L., Ebert, J.I., 2012. Environments and hominin activities across the FLK Peninsula during Zinjanthropus times (1.84 Ma), Olduvai Gorge, Tanzania. J. Hum. Evol. 63, 364-383.

Boisserie, J.-R., Guy, F., Delagnes, A., Hlukso, L.J., Bibi, F., Beyene, Y., Guillemot, C., 2008. New palaeoanthropological research in the Plio-Pleistocene Omo Group, Lower Omo Valley, SNNPR (Southern Nations, Nationalities and People Regions), Ethiopia. C.R. Palevol 7, 429-439.

Boisserie, J.-R., Delagnes, A., Beyene, Y., Schuster, M., 2010. Reconstructing the African background to human expansions in Eurasia: New research in the Shungura Formation, Ethiopia. Quatern. Int. 223-224, 426-428.

Braun, D.R., Plummer, T., Ditchfield, P., Ferraro, J.V., Maina, D., Bishop, L.C., Potts, R. 2008. Oldowan behavior and raw material transport: perspectives from the Kanjera Formation. J. Archaeol. Sci. 35, 2329-2345.

Braun, D.R., Plummer, T.W., Ditchfield, P.W., Bishop, L.C., Ferraro, J.V., 2009a. Oldowan Technology and Raw Material Variability at Kanjera South. In: Hovers, E. Braun, D.R. (Eds.), Interdisciplinary Approaches to the Oldowan, Vertebrate Paleobiology and Paleoanthropology. Springer, Dordrecht, Netherlands, pp. 99-110.

Braun, D.R., Plummer, T., Ferraro, J.V., Ditchfield, P., Bishop, L.C., 2009b. Raw material quality and Oldowan hominin toolstone preferences: evidence from Kanjera South, Kenya. J. Archaeol. Sci. 36, 1605-1614.
Burroni, D., Donahue, R.E., Pollard, A.M., Mussi, M., 2002. The Surface Alteration Features of Flint Artefacts as a Record of Environmental Processes. J. Archaeol. Sci. 29, 1277-1287.

Chavaillon, J., 1974. Témoignage de l'activité technique des Hominidés du Pléistocène ancien. Formation de Shungura, basse vallée de l'Omo, Ethiopie. In: Documents Pour Servir À L'histoire Des Civilisations Éthiopiennes. CNRS, Paris, pp. 9-19.

Chavaillon, J., 1976. Evidence for the technical practicies of Early Pleistocene hominids, Shungura Formation, Lower Omo Valley, Ethiopia. In: Coppens, Y. Howell, F.C., Isaac, G.L., Leakey, R.E. (Eds.), Earliest Man and Environments in the Lake Rudolph Basin: Stratigraphy, Paleoecology and Evolution. University of Chicago Press, Chicago, pp. 565-573.

Chavaillon, J., 1980. Le point des recherches archéologiques dans la basse vallée de l'Omo, Éthiopie. In: Leakey, R.E., Ogot, B.E. (Eds.), Presented at the VIIIe congrès panafricain de pré-histoire et d'étude du Quaternaire. Louis Leakey Memorial Institut for African Prehistory, Nairobi, p. 400.

Chavaillon, J., Piperno, M., 2004. Studies on the early Paleolithic site of Melka Kunture, Ethiopia. Istituto Italiano di Prehistoria e Protostoria, Florence.

Chu, W., Thompson, C., Hosfield, R., 2015. Micro-abrasion of flint artifacts by mobile sediments: a taphonomic approach. Archeol. Anthropol. Sci. 7, 3-11.

Colombera, L., Mountney, N.P., McCaffrey, W.D., 2013. A quantitative approach to fluvial facies models: Methods and example results. Sedimentology 60 1526-1558.

Coppens, Y., Chavaillon, J., Beden, M., 1973. Résultats de la nouvelle mission de l'Omo (campagne 1972). Découverte des restes d'Hominidés et d'une industrie sur éclats. C.R. Acad. Sci. 276, 161-163.

Courtin, J., Villa, P., 1982. Une expérience de piétinement. Bull. Soc. Prehist. Fr. 79 $117-123$.

Curray, J.R., 1956. Analysis of two-dimensional orientation data. J. Geol. 64, $117-134$.

Dechant Boaz, D., 1994. Taphonomy and the fluvial environment: examples from Pliocene deposits of the Shungura Formation, Omo Basin, Ethiopia. In: Corruccini, R.S., Ciochon, R.L. (Eds.), Integrative Paths to the Past: Paleoanthropological Advances in Honor of F. Clark Howell., Advances in Human Evolution Series. Prentice Hall, Englewood Cliffs, pp. 377-414.

Delagnes, A., 2012. The earliest Stone Age of Ethiopia in the East African context. In Sanz, N. (Ed.), Human Origin Sites and the World Heritage Convention in Africa World Heritage Papers. Unesco, Paris, pp. 101-114.

Delagnes, A., Roche, H., 2005. Late Pliocene hominid knapping skills: The case of Lokalalei 2C, West Turkana, Kenya. J. Hum. Evol. 48, 435-472.

Delagnes, A., Lenoble, A., Harmand, S., Brugal, J.-P., Prat, S., Tiercelin, J.-J., Roche, H. 2006. Interpreting pachyderm single carcass sites in the African Lower and Early Middle Pleistocene record: A multidisciplinary approach to the site of Nadung'a 4 (Kenya). J. Anthropol. Archaeol. 25, 448-465.

Delagnes, A., Boisserie, J.-R., Beyene, Y., Chuniaud, K., Guillemot, C., Schuster, M. 2011. Archeological investigations in the Lower Omo Valley (Shungura Formation, Ethiopia): New data and perspectives. J. Hum. Evol. 61, 215-222.

Eswaran, H., Beinroth, F.H., Reich, P.F., Quandt, L.A., 1999. Vertisols: Their properties, classification, distribution and management. Natural Resource Conservation Service, Soil Survey Division, USDA, Washington DC.

Faisal, A., Stout, D., Apel, J., Bradley, B., 2010. The manipulative complexity of Lower Paleolithic stone toolmaking. PLoS One 5, e13718.

Feibel, C.S., Brown, F.H., McDougall, I., 1989. Stratigraphic context of fossil hominids from the omo group deposits: Northen Turkana Basin, Kenya and Ethiopia. Am. J. Phys. Anthropol. 78, 595-622.

Flenniken, J.J., Haggarty, J.C., 1979. Trampling as an agency in the formation of edge damage: an experiment lithic technology. NW Anthropol. Res. Notes 13, 208-214.

Goldman-Neuman, T., Hovers, E., 2012. Raw material selectivity in Late Pliocene Oldowan sites in the Makaamitalu Basin, Hadar, Ethiopia. J. Hum. Evol. 62, 353-366.

Harmand, S., 2009. Variability in Raw Material Selectivity at the Late Pliocene sites of Lokalalei, West Turkana, Kenya. In: Hovers, E., Braun, D.R. (Eds.), Interdisciplinary Approaches to the Oldowan, Vertebrate Paleobiology and Paleoanthropology. Springer, Dordrecht, pp. 85-97.

Harris, J.W.K., 1997. Catalogued sites in the KBS, Okote, and Chari Members of the Koobi Fora Formation. In: Isaac, G.L., Isaac, B. (Eds.), Koobi Fora Research Project. Oxford, pp. 111-113.

de Heinzelin, J., 1983. The Omo group: archives of the international Omo Research Expedition. Musée royal de l'Afrique centrale, Tervuren.

Hovers, E., 2003. Treading carefully: site formation processes and Pliocene lithic technology. In: Martínez Moreno, J., Mora Torcal, R., de la Torre Sainz, I. (Eds.) Oldowan: Rather More than Smashing Stones, Treballs D'arqueologia. Presented at the Oldowan: Rather more than smashing stones. First Hominid technology workshop. Centre d'Estudis del Patrimoni Arqueològic de la Prehistòria, Bellaterra, pp. $145-164$.

Hovers, E., 2009. Learning from mistakes: flaking accidents and knapping skills in the assemblage of A. L. 894 (Hadar, Ethiopia). In: Schick, K., Toth, N. (Eds.), The Cutting Edge: New Approaches to the Archaeology of Human Origins. Stone Age Institut, Gospot.

Howell, F.C., Haesaerts, P., de Heinzelin, J., 1987. Depositional environments archeological occurrences and hominids from Members E and F of the Shungura Formation (Omo basin, Ethiopia). J. Hum. Evol. 16, 665-700.

Isaac, G.L., 1967. Towards the interpretation of occupation debris: some experiments and observations. Kroeber Anthropol. Soc. Pap. 37, 31-57. 
Isaac, G.L., 1981. Stone Age visiting cards: approaches to the study of early land use patterns. Patterns of the past. Cambridge University Press, Cambridge, pp. 131-155.

Isaac, G.L., Harris, J.W.K., 1997. Stone artefact assemblages: a comparative study. In Isaac, G.L., Isaac, B. (Eds.), Koobi Fora Research Project. Royaume-Uni, Oxford, pp. $262-362$.

Isaac, G.L., Harris, J.W.K., Marshall, F., 1981. Small is informative: the application of the study of mini-sites and least-effort criteria in the interpretation of the Early Pleistocene archeological record at Koobi Fora, Kenya. In: Clark, J.D., Isaac, G.L. (Eds.), Las Industrias Mas Antiguas. Presented at the X Congresso Union International de Ciencias Prehistoricas y Protohistoricas, Mexico, pp. 101-119.

Kimbel, W.H., Walter, R.C., Johanson, D.C., Reed, K.E., Aronson, J.L., Assefa, Z., Marean, C.W., Eck, G.G., Bobe, R., Hovers, E., Rak, Y, Vondra, C., Yemane, T. York, D., Chen, Y., Evensen, N.M., Smith, P.E., 1996. Late Pliocene HOMO and Oldowan Tools from the Hadar Formation (Kada Hadar Member), Ethiopia. J. Hum. Evol. 31, 549-561.

Kociánová, L., Melichar, R., 2016. OATools: An ArcMap add-in for the orientation analysis of geological structures. Comput. Geosci. 87, 67-75.

Leakey, L.S.B., Clark, J.D., 1971. Olduvai gorge. Excavation in Beds I and II, 1960-1963. Cambridge U.P, New York.

Lemorini, C., Plummer, T.W., Braun, D.R., Crittenden, A.N., Ditchfield, P.W., Bishop, L.C., Hertel, F., Oliver, J.S., Marlowe, F.W., Schoeninger, M.J., Potts, R., 2014. Old stones' song: Use-wear experiments and analysis of the Oldowan quartz and quartzite assemblage from Kanjera South (Kenya). J. Hum. Evol. 72, $10-25$.

Lenoble, A., Bertran, P., 2004. Fabric of Palaeolithic levels: methods and implications for site formation processes. J. Archaeol. Sci. 31, 457-469.

Levi-Sala, I., 1988. Processes of polish formation on flint tool surface. In: Beyries, S. (Ed.), Industries Lithiques: Tracéologie et Technologie. British Archeological Reports International Series, Oxford, pp. 83-98.

Ludwig B.V., 1999. A technological reassessment of East African Plio-Pleistocene lithic artifact assemblages. Rutgers University, New Brunswick.

de Lumley, H., Beyene, Y., 2004. Les sites préhistoriques de la région de Fejej, SudOmo, Ethiopie, dans leur contexte stratigraphique et paléontologique. ADPF-Éd. Recherche sur les civilisations, Paris.

Maurin, T., Delagnes, A., Boisserie, J.-R., 2014. Spatial behaviours of Early Oldowan toolmakers in the Shungura Formation (Lower Omo Valley, Ethiopia): Proposal for an integrated approach. C.R. Pale, vol. 13, 737-746.

McDougall, I., Brown, F.H., 2008. Geochronology of the pre-KBS Tuff sequence, Omo Group, Turkana Basin. J. Geol. Soc. 165, 549-562.

McDougall, I., Brown, F.H., Vasconcelos, P.M., Cohen, B.E., Thiede, D.S. Buchanan, M.J., 2012. New single crystal 40Ar/39Ar ages improve time scale for deposition of the Omo Group, Omo-Turkana Basin, East Africa. J. Geol. Soc. 169 213-226.

Merrick, H.V., 1976. Recent Archeological Research in the Plio-Pleistocene Deposits of the Lower Southwestern Ethiopia. In: Isaac, G.L., McCown, E.R. (Eds.), Human Origins: Louis Leakey and the East African Evidence, Perspectives on Human Evolution. WA Benjamin Advanced Book Program, Menlo Park, pp. 574-584.

Merrick, H.V., Merrick, J.P.S., 1976. Archeological occurrences of earlier Peistocene age from the Shungura formation. In: Coppens, Y., Howell, F.C., Isaac, G.L., Leakey, R.E. (Eds.), Earliest Man and Environments in the Lake Rudolph Basin: Stratigraphy, Paleoecology and Evolution. Chicago University Press, Chicago, pp. 574-584.

Merrick, H.V., Heinzelin de, J., Haesaerts, P., Howell, F., 1973. Archeological occurrences of early Pleistocene age from the Shungura Formation, lower Omo Valley, Ethiopia. Nature 242, 572-575.

Miall, A.D., 1996. The geology of fluvial deposits: sedimentary facies, basin analysis and petroleum geology. Springer-Verlag, Berlin.

Mora, R., de la Torre, I., 2005. Percussion tools in Olduvai Beds I and II (Tanzania): Implications for early human activities. J. Anthropol. Archaeol. 24, 179-192.

Njau, J., 2012. Reading Pliocene Bones. Science 336, 46-47.
Petraglia, M.D., Potts, R., 1994. Water Flow and the Formation of Early Pleistocene Artifact Sites in Olduvai Gorge, Tanzania. J. Anthropol. Archaeol. 13, 228-254.

Pickford, M., Senut, B., Roche, H., Mein, P., Ndaati, G., Obwona, P., Tuhumwire, J., 1989. Uganda palaeontology expedition: résultats de la deuxième mission (1987) dans la région de Kisegi-Nyabusosi (bassin du lac Albert, Ouganda). C.R. Acad. Sci. Ser. 2 Mec. Phys. Chim. Sci. Univers Sci. Terre 308, 1751-1758.

Plisson, H., Mauger, M., 1988. Chemical and mechanical alteration of microwear polishes: an experimental approach. Helinium 28, 3-15.

Plummer, T., 2005. Discord after discard: reconstructing aspects of Oldowan hominin behavior. In: Stahl, A.B. (Ed.), African Archaeology: A Critical Introduction., Blackwell Studies in Global Archaeology. Blackwell Publishing, Malden, pp. 55-92.

Plummer, T., Bishop, L.C., Ditchfield, P., Hicks, J., 1999. Research on Late Pliocene Oldowan Sites at Kanjera South, Kenya. J. Hum. Evol. 36, 151-170.

Rensberger, B., 1973. The Omo Research Expedition: Exploring the World of early Man. Alicia Patterson Foundation, New York.

Roche, H., Brugal, J.-P., Delagnes, A., Feibel, C.S., Harmand, S., Kibunjia, M., Prat, S., Texier, P.-J., 2003. Les sites archéologiques plio-pléistocènes de la formation de Nachukui, Ouest-Turkana, Kenya : bilan synthétique 1997-2001. C. R. Pale, vol. 2, 663-673.

Rogers, M.J., Semaw, S., 2009. From Nothing to Something: The Appearance and Context of the Earliest Archeological Record. In: Camps, M., Chauhan, P. (Eds.), Sourcebook of Paleolithic Transitions. Springer New York, New York, pp. 155-171.

Rust, B.R., 1972. Pebble Orientation in Fluvial Sediments. J. Sediment. Res. 42, 384-388.

Schick, K.D., 1986. Stone Age sites in the making: experiments in the formation and transformation of archeological occurrences. British Archeological Reports International Series, Oxford.

Schick, K.D., 1987. Modeling the formation of Early Stone Age artifact concentrations. J. Hum. Evol. 16, 789-807.

Sedimentary Petrology Seminar, S.P., 1965. Gravel Fabric in Wolf Run. Sedimentology 4, 273-283.

Semaw, S., 2000. The world's oldest stone artefacts from Gona, Ethiopia: Their implications for understanding stone technology and patterns of human evolution between 2.6-1.5 million years ago. J. Archaeol. Sci. 27, 1197-1214.

Sitzia, L., Bertran, P., Boulogne, S., Brenet, M., Crassard, R., Delagnes, A., Frouin, M. Hatté, C., Jaubert, J., Khalidi, L., Messager, E., Mercier, N., Meunier, A., Peigné, S. Queffelec, A., Tribolo, C., Macchiarelli, R., 2012. The Paleoenvironment and Lithic Taphonomy of Shi'Bat Dihya 1, a Middle Paleolithic Site in Wadi Surdud, Yemen. Geoarchaeology 27, 471-491.

Stout, D., Quade, J., Semaw, S., Rogers, M.J., Levin, N.E., 2005. Raw material selectivity of the earliest stone toolmakers at Gona, Afar, Ethiopia. J. Hum. Evol. 48, 365-380.

Stout, D., Semaw, S., Rogers, M.J., Cauche, D., 2010. Technological variation in the earliest Oldowan from Gona, Afar, Ethiopia. J. Hum. Evol. 58, 474-491.

Suwa, G., White, T.D., Howell, F.C., 1996. Mandibular postcanine dentition from the Shungura Formation, Ethiopia: Crown morphology, taxonomic allocations, and Plio-Pleistocene hominid evolution. Am. J. Phys. Anthropol 101, 247-282.

de la Torre, I., Mora, R., Domınguez-Rodrigo, M., de Luque, L., Alcalá, L., 2003. The Oldowan industry of Peninj and its bearing on the reconstruction of the technological skills of LowerPleistocene hominids. J. Hum. Evol. 44, 203-224.

de la Torre, I., de Beaune, S.A., Davidson, I., Gowlett, J., Hovers, E., Kimura, Y., Mercader, J., 2004. Omo Revisited: Evaluating the Technological Skills of Pliocene Hominids 1. Curr. Anthropol 45, 439-465.

Wood, W.R., Johnson, D.L., 1978. A survey of disturbance processes in archeological site formation. Adv. Archaeol. Method Theory 315-381.

Yustos, P.S., Diez-Martín, F., Díaz, I.M., Duque, J., Fraile, C., Domínguez, M., 2015 Production and use of percussive stone tools in the Early Stone Age: Experimental approach to the lithic record of Olduvai Gorge, Tanzania. J. Archaeol. Sci. Rep. 2, 367-383. 